\title{
Strategic Conditions for Opening an Internet Store and Pricing Policies in a Retailer-Dominant Supply Chain
}

\author{
Yonghong Cheng ${ }^{1,2}$ and Zhongkai Xiong ${ }^{1,2}$ \\ ${ }^{1}$ School of Economics and Business Administration, Chongqing University, Chongqing 400030, China \\ ${ }^{2}$ Chongqing Key Laboratory of Logistics, Chongqing University, Chongqing 400030, China \\ Correspondence should be addressed to Zhongkai Xiong; xiongzhongkai@cqu.edu.cn
}

Received 30 May 2014; Revised 12 October 2014; Accepted 12 October 2014

Academic Editor: Hari M. Srivastava

Copyright (c) 2015 Y. Cheng and Z. Xiong. This is an open access article distributed under the Creative Commons Attribution License, which permits unrestricted use, distribution, and reproduction in any medium, provided the original work is properly cited.

\begin{abstract}
To examine when the manufacturer and dominant retailer open their own Internet stores and how setting prices to ensure opening Internet stores are profitable. We consider a two-echelon supply chain with one manufacturer and one dominant retailer. The retailer has a physical store in a monopolist market. Depending on whether the Internet stores are opened successfully by them, we firstly obtain equilibrium prices and profits under four possible supply chain structures. Secondly, we identify several strategic conditions when it is optimal to open an Internet store for the manufacturer and dominant retailer and discuss its implications. It is interesting to note that multichannel retailing is not necessarily the best strategy for the dominant retailer. In addition, we investigate the impacts of problem parameters (the dominant retailer's bargaining power and consumers' disutility of purchasing a product from Internet store) on the manufacturer and dominant retailer's pricing policies. We find that the manufacturer's optimal price at her Internet store is not always being lower than the dominant retailer's. Finally, we conduct numerical examples to illustrate the theoretical results.
\end{abstract}

\section{Introduction}

The Internet environment enables some companies to try to open their own Internet stores. In practice, the manufacturers (such as Apple, IBM, Hewlett-Packard, Dell, Nike, and Samsung) sell their products through both retailer's physical store and its Internet store. And some retailers also open Internet stores and keep their physical stores in place, such as Wal-Mart, Best Buy, Barnes \& Noble, Office Depot, Staples, GOME, and Suning Appliance, among others. However, it is acknowledged that some well-known manufacturers, such as Acer, Colgate, Gillette, and Tylenol, only sell their products exclusively through retailer's physical store, and they do not open their Internet store. On the retailers' side, such as 7Eleven and Carrefour, they do not provide the Internet stores, so consumers can only purchase products from their physical stores [1]. Consequently, a question arises. The question is that why the Internet store sometimes was opened by the manufacturers, whereas in other cases the Internet stores are opened by the retailers.
In the manufacturer's point of view, opening an Internet store not only motivates the downstream retailer to perform more effectively but also mitigates supply chain's double marginalization problem [2-7]. However, some smart consumers often get more product information and experience from the retailers' physical stores but shift to purchasing their ideal product from the manufacturer' Internet store with a lower price. Thus, these consumers' buying behavior may reduce the retailer's profit. To cope with the above free-riding problem, some retailers have no choice but to open their own Internet stores and keep physical stores in place [8-10]. Moreover, the retailers (such as Wal-Mart, Best Buy, Barnes \& Noble, and Office Depot) sell an identical product with the same price across their Internet stores and physical stores. In their views, these pricing policies can retain the advantage of their retail services and increase their sales base due to customers purchasing from their Internet stores. Those successful retailers are well known as "category killers" or "dominant retailers." However, the first paragraph illustrates that neither each manufacturer nor each retailer 
opens their own Internet stores. In addition, as Iyer and Villas-Boas [11], Dukes and Liu [12] point out that the key measurements of supply chain members features such as the dominant retailer's bargaining power in the supply chain and the consumers' disutility buying from Internet store may influence the conditions for opening an Internet store.

Although these emerging trends are particularly noticeable in the E-commerce market, there is scant literature addressing the interactions between manufacturer and dominant retailer whether to open their own Internet stores with different setup costs in a supply chain. To fill this gap in the literature, we answer the following critical problems faced by the manufacturer and dominant retailer.

(1) When should the manufacturer and dominant retailer open their own Internet stores in a supply chain?

(2) How would the manufacturer and dominant retailer differentially set retail price between their Internet stores to ensure that opening an Internet store is profitable in a competition environment?

(3) How do the manufacturer and dominant retailer adjust their pricing policies according to the dominant retailer's bargaining power in the supply chain and the consumers' disutility buying from Internet store?

Our work is intended to develop game-theoretic models to gain insights into these problems. To this end, we first formulate four possible supply chain structures (T-channel, RD-channel, MD-channel, and M-channel), which depend on whether the Internet stores are opened by the manufacturer and dominant retailer. Meanwhile, we analyse and compare the manufacturer and dominant retailer's optimal pricing policies and equilibrium profits among four supply chain structures. Our analysis suggests that no matter who opens an Internet store, the player opening Internet store will affect the supply chain structure and optimal pricing policies in different ways. It should be noted that both the manufacturer and dominant retailer's optimal choices for opening an Internet store are largely determined by their respective setup costs, which are closely related to the dominant retailer's bargaining power and consumers' disutility buying from Internet store.

The remainder of this paper is organized as follows. Section 2 reviews the related literature and shows our contributions in more detail. In Section 3, we describe the models and propose some assumptions related to our study. In Section 4, we first present the equilibrium outcomes among the different supply chain structures and then discuss the strategic conditions for the manufacturer and dominant retailer to open an Internet store. In Section 5, we investigate the impacts of the dominant retailer's bargaining power and consumers' disutility of purchasing a product from Internet store on both the manufacturer and dominant retailer's pricing strategies. In Section 6, we illustrate the theoretical results by numerical examples. We conclude the results and managerial implications and suggest topics for future research in Section 7. All relevant proofs are relegated to the appendix.

\section{Literature Review}

There is a growing amount of literature on the Internet channel management strategies in electronic commerce era. However, most of them focus on the competitive pricing decisions and channel coordination problem, in which the manufacturer sells products through both retailer's physical store and its Internet store, which is called dual-channel supply chain. In particular, a large amount of literature explore the price-setting game in a dual-channel environment [13-20]. In addition, it should be noted that when the manufacturer opens an Internet store as its direct channel, consumers have alternatives to choose store that is better suited to their needs; then the retailer's profit may reduce and result in "channel conflict." Therefore, a considerable body of research also exists on channel conflict and coordination in the dual-channel supply chain [21-27]. In those studies, they show that a manufacturer would choose one contract (i.e., quantity discounts or two-part tariffs, profit sharing contract) to coordinate the distribution channel. However, all the above papers are devoted to discussing the manufacturer and retailer's pricing strategies and channel coordination but neglect the dominance of retailer and by default the retailer is unable to open an Internet store.

Although our research is also related to the literature on the dominant retailer opening an Internet store, the literature is limited. Yao and Liu [28] propose the mixed retail and etail distribution channels and discuss the dominant retailer's pricing strategy when opening an Internet store. Liu et al. [29] develop a game-theoretical model to show that a brick-andmortar retailer can open an Internet store to preempt the etailor's entry. Cheng and Nault [30] study how existing market coverage affects the outcome of opening an Internet store game between an existing retailer and a new entrant. Zhang [31] studies the retailer's multichannel (between Internet store and physical store) and price advertising decisions. Huang and Swaminathan [32] study the optimal pricing strategies when a product is sold in two stores such as Internet store and physical store. It should be noted that the authors focus on the dominant retailer having the ability to open an Internet store but does not consider the interactions with manufacturer in a supply chain and neglect the dominant retailer's bargaining power in the distribution channel.

In contrast to the papers that are investigated above, our work differs in two important aspects. First, in the light of the manufacturer and dominant retailer having tried to open their Internet store, we assume that both of them are able to commit whether to open an Internet store in a supply chain and attempt to provide theoretical insights into the strategic conditions and pricing policies for them to open an Internet store. Interestingly, we find that the dominant retailer opening an Internet store can induce the manufacturer to open an Internet store to compete with him, and the manufacturer's optimal price at her Internet store is not always being lower than the dominant retailer's. Second, in order to characterize the dominant retailer's bargaining power in the distribution channel, we assume that the wholesale price between manufacturer and dominant retailer is derived by means of the bargaining process. In 


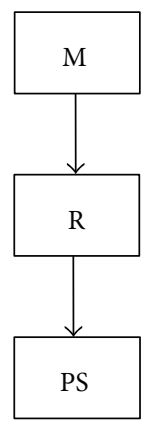

(a) $\mathrm{T}$ channel

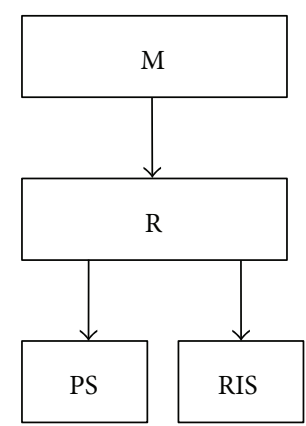

(b) RD-channel

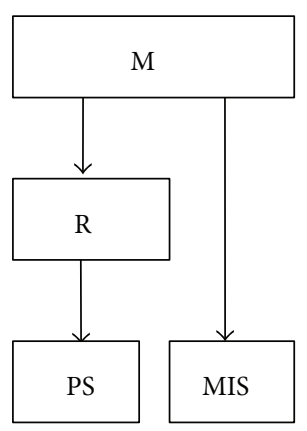

(c) MD-channel

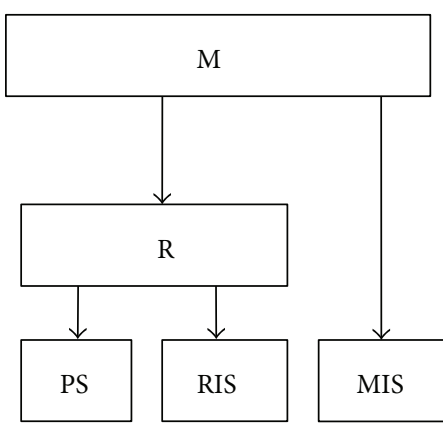

(d) M-channel

FIGURE 1: The supply chain configuration of scenarios T-, RD-, MD-, and M-channels.

our study, we note that the dominant retailer's bargaining power plays a critical role in influencing equilibrium prices and profits in the distribution system, as well as the strategic conditions for the manufacturer and dominant retailer to open an Internet store.

\section{Model Fundamentals}

Consider a two-echelon supply chain consisting of one manufacturer, denoted by M (referred to as "she"), and one dominant retailer with a physical store in a monopolist market, denoted by R (referred to as "he"), who sells the products of the manufacturer to the consumers. With the prevailing popularity of consumers purchasing products online, they have to redesign their distribution channel structures. Based on marketing cases about the manufacturer's direct channel strategy and the dominant retailer's multichannel retailing activities, we assume that each of them is able to commit whether to open an Internet store is faced with different setup costs. Since the manufacturer and dominant retailer may open the Internet stores successfully or not, there are 4 possible channel structures.

Case $(A)$. Both of them do not open their Internet stores denoted by T-channel.

Case (B). The manufacturer does not open an Internet store, but dominant retailer opens an Internet store denoted by RDchannel.

Case $(C)$. The manufacturer opens an Internet store, but dominant retailer does not and is denoted by MD-channel.

Case $(D)$. Both of them open their Internet stores simultaneously denoted by M-channel.

Figure 1 depicts 4 possible cases. For convenience, let PS denotes the dominant retailer's physical store; MIS, the manufacturer-owned Internet store; RIS, the dominant retailer-owned Internet store.

Parameters and decision variables' notations used in the paper are listed in Abbreviations section.
Before establishing the models, we give some assumptions related to this study as follows.

Assumption 1. The manufacturer produces the product at a constant unit (marginal) cost which is normalized to zero and sells product to the dominant retailer with a wholesale price $w^{\mathrm{j}}=(1-\beta) p_{r}^{\mathrm{j}}$ in the $\mathrm{j}$-channel, which is derived by means of the bargaining process, where $p_{r}^{j}$ is the retail price charged by the dominant retailer in the $\mathrm{j}$-channel, and the value of $\beta \epsilon$ $(0,1)$ denotes his bargaining power. The wholesale price that is determined in the supply chain by a negotiation process is similar to the previous researches such as [11, 12].

Assumption 2. The dominant retailer acts as a Stackelberg price leader in the distribution channel, and his physical store has located at the left end point of a Hotelling linear city bounded between zero and one, as seen in the previous literature [29, 33-37]. Without loss of generality, we assume that the size of the market is one, and consumers are uniformly distributed over the line of the city with a unit travel cost $(t>0)$ for traveling to the dominant retailer's physical store to shop, and each consumer buys at most one unit of the product.

Assumption 3. The dominant retailer sets the same price across his physical store and Internet store. In marketing practice, some dominant retailers, such as Circuit City, Tiffany, Gap, and Staples, fully integrate their offline and online operations, which can make consumer not figure out whether it is cheaper to purchase from its physical stores and Internet stores. In fact, this assumption is similar to $[29,31,38]$.

Assumption 4. The value of consumers willing to pay for the product is sufficiently large $(V>t)$, so as to ensure the full market coverage. Otherwise, the dominant retailer never opens a physical store to serve consumers.

Assumption 5. If a consumer chooses to purchase the product from the Internet stores (MIS or RIS), the purchasing incurs a unit disutility $(\delta>0)$. To ensure that at least one of the manufacturers and the dominant retailer has an incentive to 
TABLE 1

\begin{tabular}{lccccc}
\hline & M's wholesale price & MIS's price & PS/RIS's price & M's profit & R's profit \\
\hline T-channel & $(1-\beta)(V-t)$ & N/A & $V-t$ & $(1-\beta)(V-t)$ & $(1-\beta)(V-\delta)$ \\
\hline RD-channel & $(1-\beta)(V-\delta)$ & N/A & $V-\delta$ & $\beta(V-\delta)-F_{r}$ \\
\hline \multirow{2}{*}{ MD-channel } & $\frac{(1-\beta)(t+\delta)}{2 \beta}$ & $\frac{(2+\beta) t+(2-3 \beta) \delta}{4 \beta}$ & $\frac{t+\delta}{2 \beta}$ & $\frac{t+\delta}{2 \beta}+\frac{(t-\delta)^{2}-12 t \delta}{16 t}-F_{m}$ & $\frac{(t+\delta)^{2}}{8 t}$ \\
\hline
\end{tabular}

TABLE 2

\begin{tabular}{|c|c|c|c|c|c|}
\hline & M's wholesale price & MIS's price & PS/RIS's price & M's profit & R's profit \\
\hline$\delta<\frac{t}{2}$ & $(1-\beta)(t-\delta)$ & $t-\delta$ & $t-\delta$ & $t-\delta-(t-\delta) \delta$ & $(t-\delta) \delta-F$ \\
\hline$\delta<\overline{3}$ & $\beta$ & $\bar{\beta}$ & $\bar{\beta}$ & $\bar{\beta}-\frac{t}{t}-F_{m}$ & $t-F_{r}$ \\
\hline$\delta>t$ & $(1-\beta)(t+\delta)$ & $(2+\beta) t+(2-3 \beta) \delta$ & $t+\delta$ & $t+\delta \quad(t-\delta)^{2}-12 t \delta$ & $(t+\delta)^{2}$ \\
\hline$O>\overline{3}$ & $2 \beta$ & $\begin{array}{c}4 \beta \\
\end{array}$ & $\overline{2 \beta}$ & $16 t$ & $8 t$ \\
\hline
\end{tabular}

open an Internet store, let $\delta<t$ in our study, which is similar to previous studies $[3,14,17]$.

Consumers' disutility $\delta$ capturing various factors makes online shopping inconvenient, such as quality uncertainty (e.g., the inability to touch and feel), discomfort with online security, waiting time until delivery, and shipping charge.

Based on the above assumptions, it is clear that, for a consumer located at $x \in[0,1]$, he will get utilities $U_{\mathrm{PS}}=$ $V-p_{r}-t x$ when purchasing the product from the dominant retailer's physical store, and $U_{\text {MIS }}=V-p_{m}-\delta$ when purchasing the product from the manufacturer's Internet store, and $U_{\mathrm{RIS}}=V-p_{r}-\delta$ when purchasing the product from the dominant retailer's Internet store.

\section{Equilibrium Outcomes and Strategic Conditions for Opening an Internet Store}

In this section, we first present the equilibrium outcomes among the different channel structures and then discuss the strategic conditions for the manufacturer and dominant retailer to open their Internet stores. The equilibrium outcomes are given by the following Lemmas 6 and 7, and the proofs are provided in Appendix A.

\subsection{Equilibrium Outcomes}

Lemma 6. In the T-channel, MD-channel, and RD-channel, the equilibrium prices and profits for the manufacturer and dominant retailer can be summarized as shown in Table 1.

Lemma 7. In the M-channel, the equilibrium prices and profits for manufacturer and dominant retailer can be summarized as shown in Table 2.

From Lemmas 6 and 7, we observe that no matter the manufacturer and dominant retailer open an Internet store will affect the supply chain structure and equilibrium prices and profits in different ways. Let T-channel be a benchmark; we note that the dominant retailer should lower retail price only when his Internet store in the market, and when the setup cost of opening an Internet store $F_{r}<\beta(t-\delta)$, then he can get more profit than that of not opening an Internet store. In addition, we find that when the manufacturer and dominant retailer open their Internet stores simultaneously, if consumers' disutility of purchasing a product from Internet store is low enough (i.e., $\delta<t / 3$ ), the manufacturer can set the retail price at her Internet store same to the dominant retailer's retail price. However, if consumers' disutility of purchasing a product from Internet store is relatively larger (i.e., $\delta>t / 3$ ), the equilibrium prices are same to the case of the manufacturer only open an Internet store, that is, MD-channel. Furthermore, the manufacturer's profit does not change, but the dominant retailer's profit decreases. Therefore, we will discuss the strategic conditions for the manufacturer and dominant retailer to open an Internet store according to the equilibrium profits among the different channel structures.

4.2. Strategic Conditions for Opening an Internet Store. Now, as one of the critical problems to obtain the strategic conditions for the manufacturer and dominant retailer to open an Internet store, we compare the equilibrium profits in $\mathrm{RD}$ channel, MD-channel, and M-channel to the equilibrium profits in T-channel and compare the equilibrium profits in M-channel to the equilibrium profits in $\mathrm{RD}$-channel and MD-channel, respectively. The following propositions and corollaries summarize the strategic conditions and its implications. The proofs are given in Appendix B.

Proposition 8. Suppose that the manufacturer has not opened an Internet store; when the setup cost of opening an Internet store by the dominant retailer $F_{r}<\beta(t-\delta)$, he can begin to open an Internet store.

Proposition 8 implies that under the condition of the manufacturer has not opened an Internet store, only when the setup cost of opening an Internet store is relatively small, the dominant retailer will get more profit than that of not opening an Internet store. Otherwise, his profit will decrease due to costly setup cost.

Obviously, an immediate consequence of above propositions is the following corollary. 
Corollary 9. If the manufacturer has not opened an Internet store, the dominant retailer's strategic motive for opening an Internet store would be weakened by increasing consumers' disutility of purchasing a product from Internet store.

Proposition 10. Suppose that the dominant retailer has not opened an Internet store; when the setup cost of opening an Internet store by the manufacturer $F_{m}<(t+\delta) / 2 \beta+[(t-$ $\left.\delta)^{2}-12 t \delta\right] / 16 t-(1-\beta)(V-t)$, she can begin to open an Internet store.

Proposition 10 implies that, under the condition of the dominant retailer has not opened an Internet store, only when the setup cost of opening an Internet store is relatively small, the manufacturer will get more profit than that of not opening an Internet store. Otherwise, her profit will decrease due to costly setup cost.

Based on Proposition 10, we have the following corollary.

Corollary 11. If the dominant retailer has not opened an Internet store and his bargaining power is relatively small (i.e., $\beta<4 t /(7 t-\delta))$, the manufacturer's strategic motive for opening an Internet store would be strengthened by increasing consumers' disutility of purchasing a product from Internet store. Otherwise, her strategic motive would be weakened.

Proposition 12. There are two choices for the manufacturer and dominant retailer to open their Internet stores simultaneously, which are summarized as follows.

(1) If consumers' disutility of purchasing a product from Internet store is low enough (i.e., $\delta<t / 3$ ) and the setup costs of opening an Internet store by the manufacturer and dominant retailer meet $F_{m}<(t-\delta) / \beta-(t-$ $\delta) \delta / t-(1-\beta)(V-t)$ and $F_{r}<(t-\delta) \delta / t-\beta(V-t)$, respectively, both of them can open their own Internet stores simultaneously.

(2) If consumers' disutility of purchasing a product from Internet store is relatively larger (i.e., $\delta>t / 3$ ) and the setup costs of opening an Internet store by the manufacturer and dominant retailer meet $F_{m}<(t+$ $\delta) / 2 \beta+\left[(t-\delta)^{2}-12 t \delta\right] / 16 t-(1-\beta)(V-t)$ and $F_{r}<(t+\delta)^{2} / 8 t-\beta(V-t)$, respectively, both of them can open their own Internet stores simultaneously.

Proposition 12 implies that consumers' disutility of purchasing a product from Internet store plays an important role for opening Internet stores simultaneously by the manufacturer and dominant retailer. And only when the setup costs of opening Internet stores by them are relatively small, respectively, then both will get more profit than that of not opening Internet stores. Otherwise, their profits will decrease due to costly setup costs.

It should be noted that the upper bounds of $F_{m}$ and $F_{r}$ are related to $\delta$ for a given $\beta$ in Proposition 12, so we have the following corollary.

Corollary 13. If both the manufacturer and dominant retailer have not operated their Internet stores, then
(1) when consumers' disutility of purchasing a product from Internet store is low enough (i.e., $\delta<t / 3$ ), the manufacturer's strategic motive for opening an Internet store would be weakened by increasing consumers' disutility of purchasing a product from Internet store, but the dominant retailer's strategic motive for opening an Internet store would be strengthened;

(2) when consumers' disutility of purchasing a product from Internet store is relatively larger (i.e., $\delta>t / 3$ ), the dominant retailer's strategic motive for opening an Internet store would be strengthened by increasing consumers' disutility of purchasing a product from Internet store. For the manufacturer, only if the dominant retailer's bargaining power is relatively small (i.e., $\beta<$ $4 t /(7 t-\delta))$, her strategic motive for opening an Internet store would be strengthened by increasing consumers' disutility of purchasing a product from Internet store. Otherwise, her strategic motive would be weakened.

Proposition 14. Suppose that the dominant retailer has operated an Internet store, the manufacturer has two choices to open an Internet store, which are summarized as follows.

(1) If consumers' disutility of purchasing a product from Internet store is low enough (i.e., $\delta<t / 3$ ), and the setup cost of opening an Internet store by the manufacturer $F_{m}<(t-\delta) / \beta-(t-\delta) \delta / t-(1-\beta)(V-\delta)$, she can also open an Internet store.

(2) If consumers' disutility of purchasing a product from Internet store is relatively larger (i.e., $\delta>t / 3$ ), and the setup cost of opening an Internet store by the manufacturer $F_{m}<(t+\delta) / 2 \beta+\left[(t-\delta)^{2}-12 t \delta\right] / 16 t-$ $(1-\beta)(V-\delta)$, she can also open an Internet store.

Proposition 14 implies that, under the condition of the dominant retailer has operated an Internet store, consumers' disutility of purchasing a product from Internet store also plays an important role in opening an Internet store by the manufacturer. And only when the setup cost of opening an Internet store is relatively small, then the manufacturer will get more profit than that of not opening an Internet store. Otherwise, her profit will decrease due to costly set-up cost.

Based on Proposition 14, we have the following corollary.

Corollary 15. If the dominant retailer has operated an Internet store, then

(1) when consumers' disutility of purchasing a product from Internet store is low enough (i.e. $\delta<t / 3$ ), the manufacturer's strategic motive for opening an Internet store would be weakened by increasing consumers' disutility of purchasing a product from Internet store.

(2) when consumers' disutility of purchasing a product from Internet store is relatively larger (i.e. $\delta>t / 3$ ), and only if the dominant retailer's bargaining power is relatively small (i.e. $\beta<\left[(t+\delta)+\sqrt{(t+\delta)^{2}+128 t^{2}}\right] / 16 t$ ), the manufacturer's strategic motive for opening an Internet store would be strengthened by increasing 
consumers' disutility of purchasing a product from Internet store. Otherwise, her strategic motive would be weakened.

Proposition 16. Suppose that the manufacturer has operated an Internet store; the best choice for dominant retailer is not to open an Internet store.

Proposition 16 implies that, under the condition of the manufacturer has operated an Internet store, regardless of consumers' disutility of purchasing a product from Internet store is small or larger, it is best for the dominant retailer not to open an Internet store. Otherwise, his profit will decrease due to costly setup cost or the manufacturer's low price strategy that attract more consumers to buy the product from her Internet store.

Proposition 17. Suppose that the manufacturer has not opened an Internet store, if consumers' disutility of purchasing a product from Internet store is low enough (i.e., $\delta<t / 3$ ), and the setup cost of opening an Internet store for the manufacturer is intermediate $F_{m} \in\left[(t+\delta) / 2 \beta+\left[(t-\delta)^{2}-12 t \delta\right] / 16 t,(t-\right.$ $\delta) / \beta-(t-\delta) \delta / t]$, the dominant retailer opening an Internet store can lead to the well-known contagion-like effect.

Proposition 17 implies that under the condition of the manufacturer has not opened an Internet store, when consumers' disutility of purchasing a product from Internet store is relatively small, and the set-up cost of opening an Internet store for the manufacturer is intermediate, the dominant retailer's Internet store entry may induce the manufacturer to open her own Internet store competing with him.

From Proposition 17, we observe that the upper and lower bounds of $F_{m}$ are related to $\delta$ for a given $\beta$, so we have the following corollary.

Corollary 18. When consumers' disutility of purchasing a product from Internet store is low enough (i.e., $\delta<t / 3$ ), if the dominant retailer's bargaining power is relatively small (i.e., $\beta<4 t /(7 t-\delta))$, the contagion-like effect would be expanded by increasing consumers' disutility of purchasing a product from Internet store. However, if the dominant retailer's bargaining power is relatively larger (i.e., $\beta>4 t /(7 t-\delta)$ ), the contagionlike effect would be diminished.

Based on aforementioned propositions, we now show when do the manufacturer and dominant retailer open their own Internet stores to a traditional supply chain and how do they set prices after opening Internet stores in Table 3.

\section{Analytical Results on Both Players' Pricing Policies}

From Lemmas 6 and 7, we know that the T-channel and $\mathrm{RD}$-channel are monopoly settings. So the dominant retailer charges the optimal monopoly price and sells the product to all consumers. However, under the MD-channel and Mchannel, the manufacturer and dominant retailer engage in price competition. To investigate the impacts of the dominant retailer's bargaining power and consumers' disutility of purchasing a product from Internet store on the manufacturer and dominant retailer's pricing strategies, we obtain the following propositions, and the proofs are provided in Appendix C.

Proposition 19. Suppose that only the manufacturer can open an Internet store, then

(1) $\partial p_{m}^{M D} / \partial \beta=\partial p_{r}^{M D} / \partial \beta=-(t+\delta) / 2 \beta^{2}<0$;

(2) $\partial p_{r}^{M D} / \partial \delta=1 / 2 \beta>0$, and $\partial p_{m}^{M D} / \partial \delta=(2-3 \beta) / 4 \beta$, and if $\beta \in(0,2 / 3)$, then $\partial p_{m}^{M D} / \partial \delta>0$, if $\beta \in(2 / 3,1)$, then $\partial p_{m}^{M D} / \partial \delta<0$;

(3) if $\delta<t / 3$, then $p_{m}^{M D}>p_{r}^{M D}$, if $\delta=t / 3$, then $p_{m}^{M D}=$ $p_{r}^{M D}$, and if $\delta>t / 3$, then $p_{m}^{M D}<p_{r}^{M D}$.

Proposition 19 indicates that when the manufacturer can open an Internet store,

(1) she should also lower the price to induce consumers to purchase the product from her Internet store as the increasing dominant retailer's bargaining power; otherwise, the dominant retailer will also provide price incentives for consumers to buy the product from his physical store;

(2) if the dominant retailer's bargaining power is relatively small (i.e., $\beta<2 / 3$ ), she should raise the price in her Internet store with increasing consumers' disutility; However, if the dominant retailer's bargaining power is relatively larger (i.e., $\beta>2 / 3$ ), she should cut down the price in her Internet store with increasing consumers' disutility;

(3) if consumers' disutility of purchasing a product from Internet store is relatively larger (i.e., $\delta>t / 3$ ), she must provide strong price incentives for consumers to purchase the product from her Internet store; otherwise her profits will cut down owing to some consumers buying the product from the dominant retailer's physical store; on the contrary, the dominant retailer will provide strong price incentives for consumers to purchase the product from his physical store when consumers' disutility of purchasing a product from Internet store is low enough (i.e., $\delta<$ $t / 3$ ), then the manufacturer's retail price is higher than the dominant retailer's. If and only if consumers' disutility of purchasing a product from Internet store satisfies $\delta=t / 3$, the manufacturer can set her retail price to be equal to the dominant retailer's.

Proposition 20. Suppose that both the manufacturer and dominant retailer can open their Internet stores simultaneously, then.

(1) If $\delta<t / 3$, then $\partial p_{m}^{M} / \partial \beta=\partial p_{r}^{M} / \partial \beta=-(t-\delta) / \beta^{2}<0$, $\partial p_{m}^{M} / \partial \delta=\partial p_{r}^{M} / \partial \delta=-1 / \beta<0$.

(2) If $\delta>t / 3$, then $\partial p_{m}^{M} / \partial \beta=\partial p_{r}^{M} / \partial \beta=-(t+\delta) / 2 \beta^{2}<$ $0, \partial p_{m}^{M} / \partial \delta=(2-3 \beta) / 4 \beta, \partial p_{r}^{M} / \partial \delta=1 / 2 \beta>0$, and 
TABLE 3: Strategic conditions for opening Internet stores to T-channel and pricing policies.

\begin{tabular}{|c|c|c|}
\hline Strategic conditions & M and R's activities & Pricing policies \\
\hline $\begin{array}{l}\text { M has not opened an Internet store and } \\
F_{r}<\beta(t-\delta)\end{array}$ & R can open an Internet store & Monopoly pricing \\
\hline $\begin{array}{l}\mathrm{R} \text { has not opened an Internet store and } \\
F_{m}<(t+\delta) / 2 \beta+\left[(t-\delta)^{2}-12 t \delta\right] / 16 t-(1-\beta)(V-t)\end{array}$ & M can open an Internet store & $\begin{array}{c}\text { When } \delta<t / 3, \\
\text { then } p_{m}^{\mathrm{MD}}>p_{r}^{\mathrm{MD}} \\
\text { When } \delta=t / 3 \text {, } \\
\text { then } p_{m}^{\mathrm{MD}}=p_{r}^{\mathrm{MD}} \\
\text { When } \delta>t / 3 \text {, } \\
\text { then } p_{m}^{\mathrm{MD}}<p_{r}^{\mathrm{MD}}\end{array}$ \\
\hline $\begin{array}{l}\text { When } \delta<t / 3, F_{r}<(t-\delta) \delta / t-\beta(V-t) \text { and } \\
F_{m}<(t-\delta) / \beta-(t-\delta) \delta / t-(1-\beta)(V-t) \\
\text { When } \delta>t / 3, F_{r}<(t+\delta)^{2} / 8 t-\beta(V-t) \text { and } \\
F_{m}<(t+\delta) / 2 \beta+\left[(t-\delta)^{2}-12 t \delta\right] / 16 t-(1-\beta)(V-t)\end{array}$ & Both $\mathrm{M}$ and $\mathrm{R}$ can open their Internet stores simultaneously & $\begin{array}{l}p_{m}^{\mathrm{M}}=p_{r}^{\mathrm{M}} \\
p_{m}^{\mathrm{M}}<p_{r}^{\mathrm{M}}\end{array}$ \\
\hline
\end{tabular}

when $\beta \in(0,2 / 3)$, then $\partial p_{m}^{M} / \partial \delta>0$, but when $\beta \epsilon$ $(2 / 3,1)$, then $\partial p_{m}^{M} / \partial \delta<0$.

(3) If $\delta \leq 3 / t$, then $p_{m}^{M}=p_{r}^{M}$; if $\delta>t / 3$, then $p_{m}^{M}<p_{r}^{M}$.

Proposition 20 indicates when both the manufacturer and dominant retailer can open their Internet stores simultaneously.

(1) If consumers' disutility of purchasing a product from Internet store is low enough (i.e., $\delta<t / 3$ ), both of them can set same price and lower prices as the increasing consumers' disutility. On the contrary, if consumers' disutility of purchasing a product from Internet store is relatively larger (i.e., $\delta>t / 3$ ), the manufacturer must provide lower price incentives than the dominant retailer, which may induce consumers to purchase the product from her Internet store. It should be pointed out that when the dominant retailer's bargaining power is relatively small (i.e., $\beta<2 / 3$ ), the manufacturer's price increases with increasing consumers' disutility, but when the dominant retailer's bargaining power is relatively larger (i.e., $\beta>2 / 3$ ), the manufacturer's retail price decreases with increasing consumers' disutility.

(2) When consumers' disutility of purchasing a product from Internet store is low enough (i.e., $\delta<$ $t / 3$ ), the dominant retailer's price decreases reduce with increasing consumers' disutility, but when consumers' disutility of purchasing a product from Internet store is relatively larger (i.e., $\delta>t / 3$ ), the dominant retailer's price decreases with increasing consumers' disutility. Speaking frankly, that is the dominant retailer's smart pricing strategies. The dominant retailer will raise the retail price when most of consumers with a large disutility of purchasing a product from Internet store buy the product from his physical store and lower the retail price when most of consumers with a small disutility of purchasing a product from Internet store buy the product from the manufacturer's Internet store.
Proposition 21. Given that the dominant retailer's bargaining power, we obtain the following results about the manufacturer's wholesale price under RD-channel, MD-channel, and $M$ channel:

(1) $\partial w^{R D} / \partial \delta=-(1-\beta)<0$;

(2) $\partial w^{M D} / \partial \delta=(1-\beta) / 2 \beta>0$;

(3) if $\delta<t / 3$, then $\partial w^{M} / \partial \delta=-(1-\beta) / \beta<0$; if $\delta>t / 3$, then $\partial w^{M} / \partial \delta=(1-\beta) / 2 \beta>0$.

Proposition 21 indicates that the manufacturer should set the wholesale prices differentially across the RD-channel, MD-channel, and M-channel and raise or lower the wholesale prices in the light of consumers' disutility of buying the product from Internet store. More specifically, the manufacturer can lower the wholesale price with increasing consumers' disutility of buying the product from Internet store in the RD-channel, but in the MD-channel, she can raise the wholesale price with increasing consumers' disutility of buying from Internet store. However, in the M-channel, when the consumers' disutility of buying from Internet store is low enough (i.e., $\delta<t / 3$ ), she can lower the wholesale price with increasing consumers' disutility, but when consumers' disutility of buying from Internet store is relatively larger (i.e., $\delta>t / 3$ ), she should raise the wholesale price with increasing consumers' disutility.

Proposition 22. Given that the dominant retailer's bargaining power, we obtain the following results about the manufacturer's retail price at her Internet store under MD-channel and Mchannel.

(1) If $\delta<t / 3$, when $\beta \in(0,2 / 3)$, then $\partial p_{m}^{M D} / \partial \delta=$ $(2-3 \beta) / 4 \beta>0, \partial p_{m}^{M} / \partial \delta=-1 / \beta<0$, but when $\beta \epsilon$ $(2 / 3,1)$, then $\partial p_{m}^{M D} / \partial \delta=(2-3 \beta) / 4 \beta<0, \partial p_{m}^{M} / \partial \delta=$ $-1 / \beta<0$.

(2) If $\delta>t / 3$, when $\beta \in(0,2 / 3)$, then $\partial p_{m}^{M D} / \partial \delta=$ $\partial p_{m}^{M} / \partial \delta>0$, but when $\beta \in(2 / 3,1)$, then $\partial p_{m}^{M D} / \partial \delta=$ $\partial p_{m}^{M} / \partial \delta<0$.

Proposition 22 indicates that the manufacturer should set the retail prices at her Internet store differentially across the 
MD-channel and M-channel and raise or lower the prices in the light of consumers' disutility of buying the product from Internet store. More specifically, if the consumers' disutility of buying from Internet store is low enough (i.e., $\delta<t / 3$ ), the manufacturer can raise the retail price at her Internet store with increasing consumers' disutility of buying from Internet store when the dominant retailer's bargaining power is relatively small (i.e., $\beta<2 / 3$ ) and the dominant retailer does not open Internet store. However, if the dominant retailer also opens an Internet store, the manufacturer should lower the retail price at her Internet store so as to attract consumers to buy the product from her Internet store. On the contrary, if the consumers' disutility of buying from Internet store is relatively larger (i.e., $\delta>t / 3$ ) and the dominant retailer also opens an Internet store, then the manufacturer should set the same price with the dominant retailer's and adjust the price following the dominant retailer.

Proposition 23. Given that the dominant retailer's bargaining power, we obtain the following results about dominant retailer's retail price under $R D$-channel, MD-channel, and M-channel:

(1) If $\delta<t / 3$, then $\partial p_{r}^{R D} / \partial \delta=-1<0, \partial p_{r}^{M D} / \partial \delta=1 / 2 \beta>$ 0 , and $\partial p_{r}^{M} / \partial \delta=-1 / \beta<0$.

(2) If $\delta>t / 3$, then $\partial p_{r}^{R D} / \partial \delta=-1<0, \partial p_{r}^{M D} / \partial \delta=$ $1 / 2 \beta>0$, and $\partial p_{r}^{M} / \partial \delta=1 / 2 \beta>0$.

Proposition 23 indicates that no matter when the consumers' disutility of buying from Internet store is small or larger, the dominant retailer should lower the retail price with increasing consumers' disutility buying from Internet store in the RD-channel, but in the MD-channel, he always raises the retail price with increasing consumers' disutility. However, in the M-channel, when consumers' disutility buying from Internet store is low enough (i.e., $\delta<t / 3$ ), he should lower the price with increasing consumers' disutility, but when consumers' disutility is relatively larger (i.e., $\delta>t / 3$ ), he can set the price same as the price in the MD-channel and raise the price with increasing consumers' disutility.

\section{Numerical Examples}

In this section, we present numerical examples to illustrate the theoretical results about impacts of consumers' disutility of buying from Internet store on the manufacturer and dominant retailer's pricing policies with different bargaining power for the dominant retailer's among RD-channel, MDchannel, and M-channel, which are summarized in Figures $2-11$, where $V=14, t=6, \delta \in(0,6)$, and $\beta=0.2, \beta=0.8$. The parameters' values satisfy the assumptions in Section 3 in order to make the models feasible and meaningful.

Comparing Figure 2 with Figure 3, we can observe that when the dominant retailer's bargaining power is relatively small (i.e., $\beta=0.2$ ); both of them can increase prices as increasing consumers' disutility of purchasing from Internet store in MD-channel. However, when the dominant retailer's bargaining power is relatively larger (i.e., $\beta=0.8$ ), the manufacturer has no choice but to lower the retail price so as to attract consumers to buy the product from her Internet

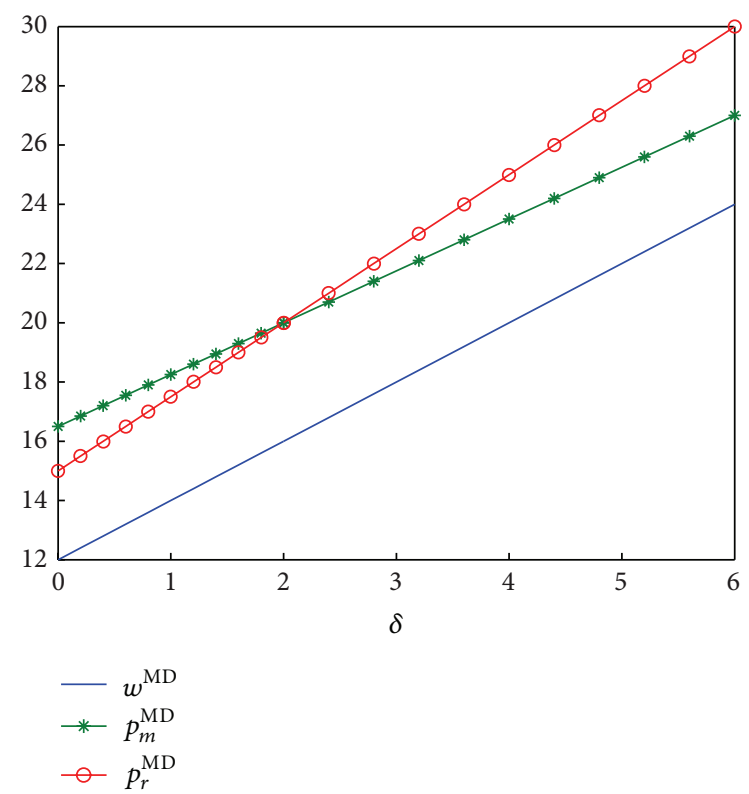

FIgURE 2: Impacts of $\delta$ on prices in the MD-channel when $\beta=0.2$.

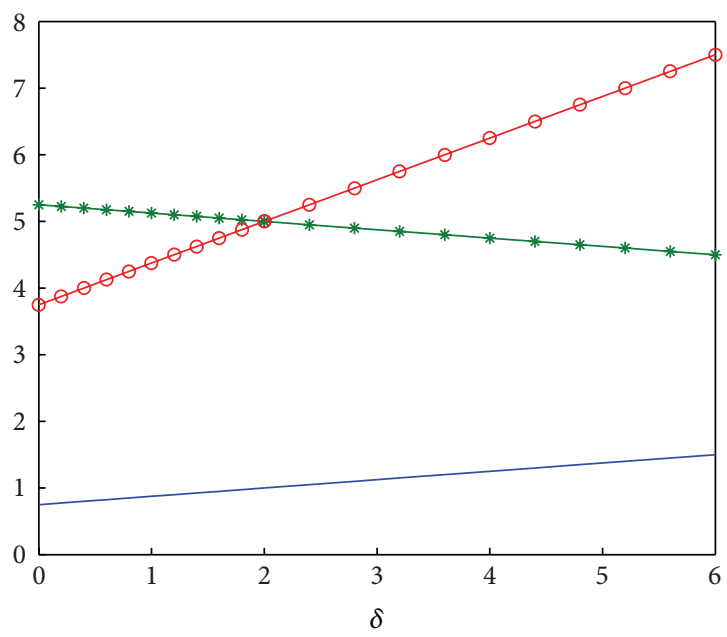

$$
\begin{aligned}
& -w^{\mathrm{MD}} \\
& -p_{m}^{\mathrm{MD}} \\
& -p_{r}^{\mathrm{MD}}
\end{aligned}
$$

FIgURE 3: Impacts of $\delta$ on prices in the MD-channel when $\beta=0.8$.

store. In addition, Figures 2 and 3 show that when consumers' disutility buying from Internet store is low enough (i.e., $\delta<$ 2 ), the manufacturer can set her retail price to be larger than the dominant retailer's. However, when consumers' disutility buying from Internet store is relatively larger (i.e., $\delta>2$ ), the manufacturer can set her retail price to be lower than the dominant retailer's.

Figures 4 and 5 show that when consumers' disutility buying from Internet store is low enough (i.e., $\delta<2$ ), both the manufacturer and dominant retailer should lower prices to increase consumers' disutility buying from Internet 


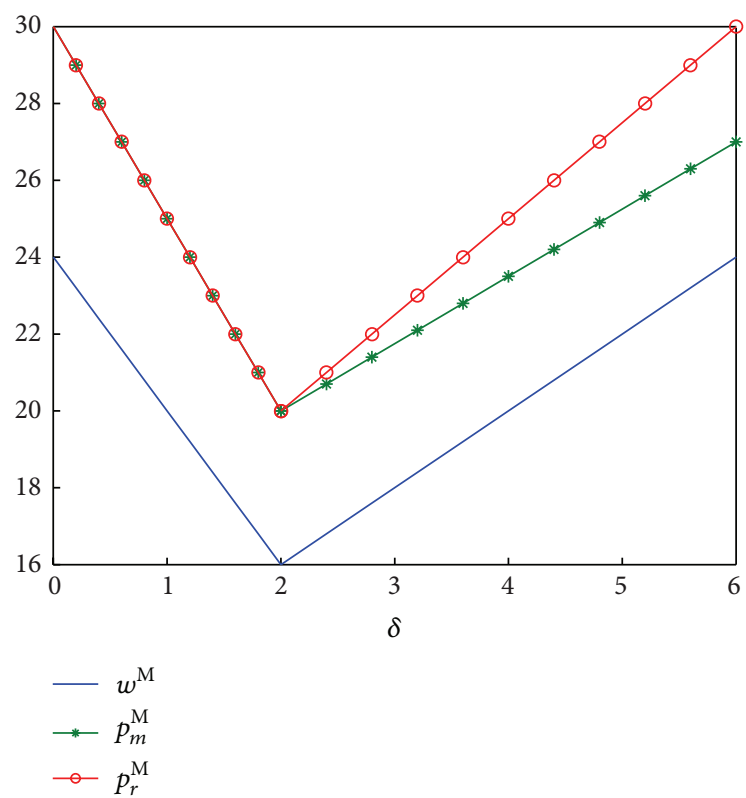

FIGURE 4: Impacts of $\delta$ on prices in the M-channel when $\beta=0.2$.

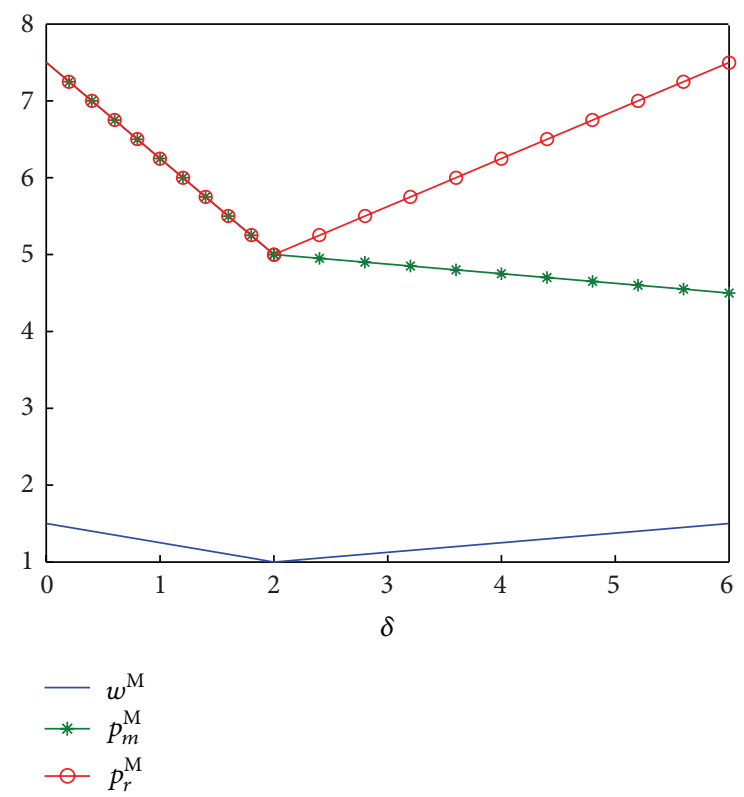

Figure 5: Impacts of $\delta$ on prices in the M-channel when $\beta=0.8$.

store. It is noted that the rate of change of manufacturer's retail price with respect to consumers' disutility buying from Internet store is equal to that of dominant retailer's retail price. However, when consumers' disutility buying from Internet store is relatively larger (i.e., $\delta>2$ ), if the dominant retailer's bargaining power is relatively small (i.e., $\beta=$ 0.2 ), the manufacturer can raise retail price following the dominant retailer as increasing consumers' disutility buying from Internet store; if the dominant retailer's bargaining power is relatively larger (i.e., $\beta=0.8$ ), the manufacturer should cut down the retail price in her Internet store with increasing consumers' disutility.

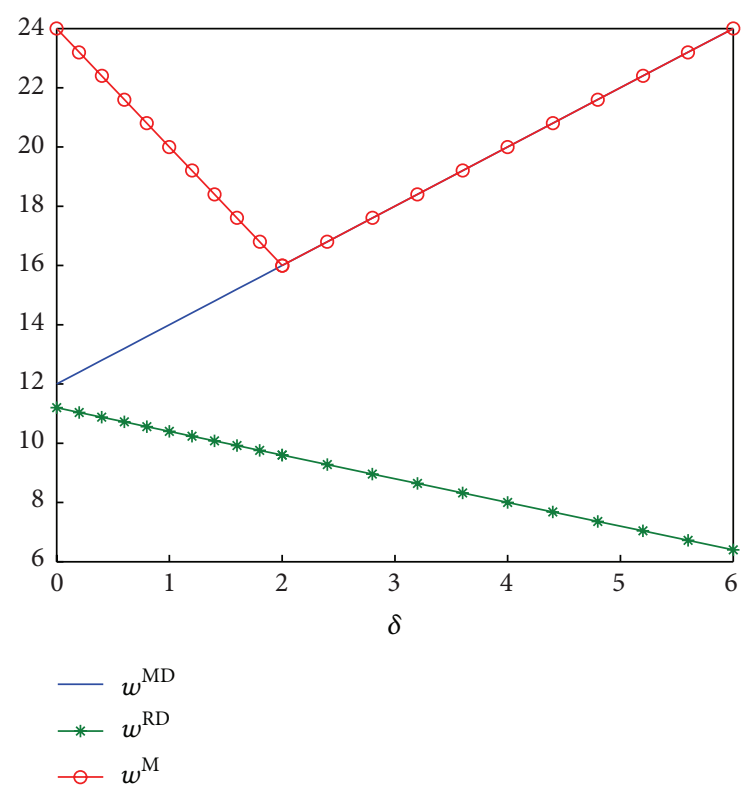

FIgURE 6: The wholesale prices in different channels when $\beta=0.2$.

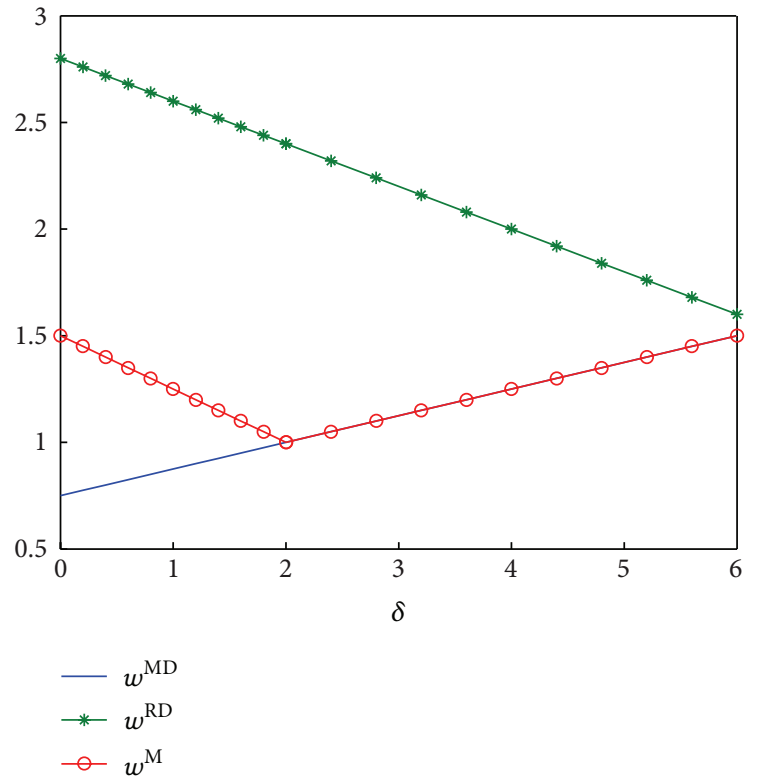

Figure 7: The wholesale prices in different channels when $\beta=0.8$.

Figures 6 and 7 show that no matter whether the dominant retailer's bargaining power is small or large, the manufacturer can raise the wholesale price with increasing consumers' disutility buying from Internet store in the MDchannel, but in the RD-channel, the manufacturer should lower the wholesale price with increasing consumers' disutility. However, in the M-channel, when consumers' disutility buying from Internet store is low enough (i.e., $\delta<2$ ), the manufacturer should lower the wholesale price with increasing consumers' disutility; when consumers' disutility buying from Internet store is relatively larger (i.e., $\delta>2$ ), the manufacturer can raise the wholesale price with increasing 


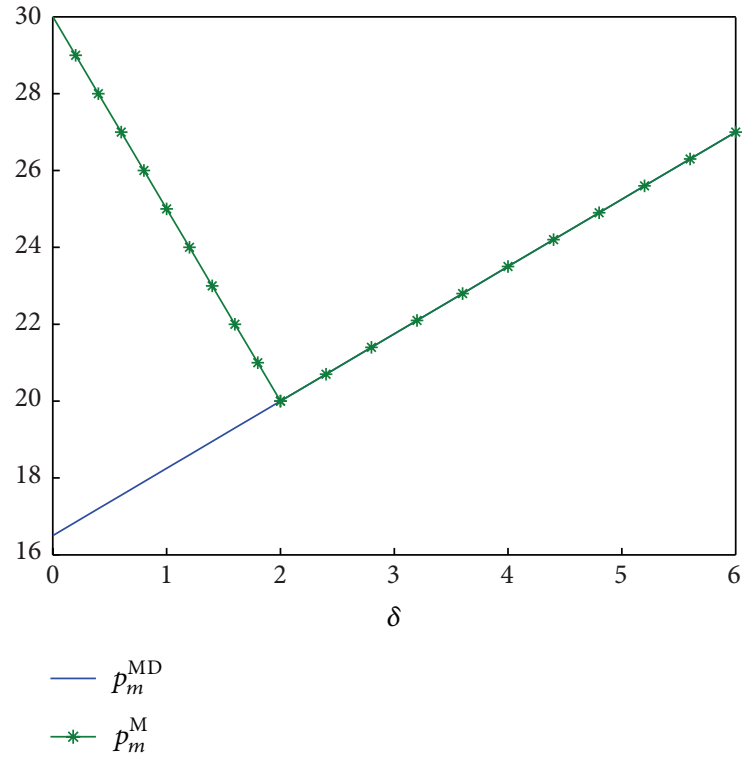

FIGURE 8: Manufacturer's retail prices in different channels when $\beta=0.2$.

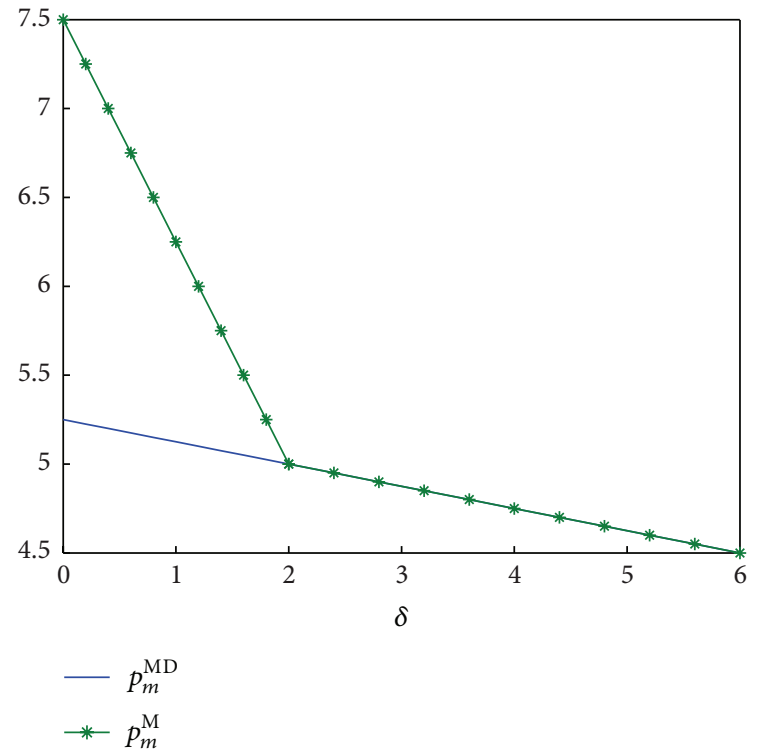

FIGURE 9: Manufacturer's retail prices in different channels when $\beta=0.8$.

consumers' disutility and set the wholesale price the same as in the MD-channel.

Figures 8 and 9 show that when the dominant retailer's bargaining power is relatively small (i.e., $\beta=0.2$ ) in the $\mathrm{MD}$-channel, the manufacturer can raise retail price with increasing consumers' disutility buying from Internet store, but when the dominant retailer's bargaining power is relatively larger (i.e., $\beta=0.8$ ), the manufacturer should lower retail price with increasing consumers' disutility. However, in the M-channel, no matter whether the dominant retailer's bargaining power is small or large, when consumers' disutility

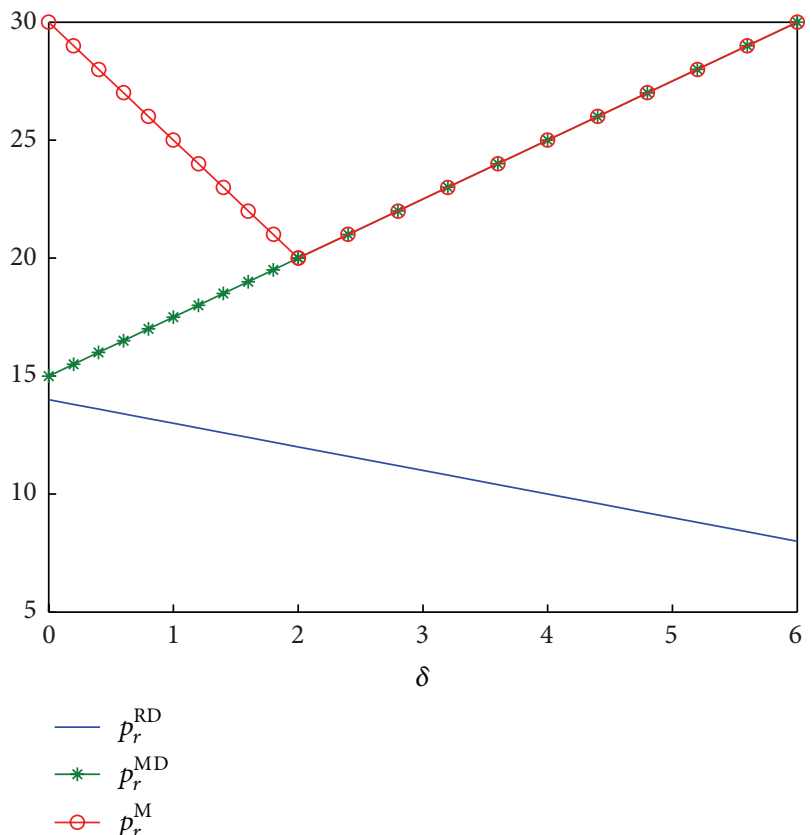

FIGURE 10: Dominant retailer's prices in different channels when $\beta=$ 0.2 .

buying from Internet store is low enough (i.e., $\delta<2$ ), the manufacturer should lower retail price with increasing consumers' disutility, but when consumers' disutility buying from Internet store is relatively larger (i.e., $\delta>2$ ), if the dominant retailer's bargaining power is relatively small (i.e., $\beta=0.2$ ), the manufacturer can raise retail price with increasing consumers' disutility buying from Internet store; if the dominant retailer's bargaining power is relatively larger (i.e., $\beta=0.8$ ), the manufacturer should lower retail price with increasing consumers' disutility.

Figures 10 and 11 show that no matter whether the dominant retailer's bargaining power is small or larger, he always lowers the retail price with increasing consumers' disutility buying from Internet store in the RD-channel, but in the MD-channel, he always raises the retail price with increasing consumers' disutility. However, in the M-channel, when consumers' disutility buying from Internet store is low enough (i.e., $\delta<2$ ), the dominant retailer should lower retail price with increasing consumers' disutility, but when consumers' disutility is relatively larger (i.e., $\delta>2$ ), the dominant retailer can raise retail price with increasing consumers' disutility buying from Internet store.

\section{Conclusions and Future Research}

To investigate when the manufacturer and dominant retailer open their own Internet stores with different setup costs and how set prices to ensure opening Internet stores are profitable in a supply chain, we first present the equilibrium outcomes under four possible supply chain structures and then discuss the strategic conditions for the manufacturer and dominant retailer when it is optimal to open an Internet store. In addition, we analyze both players' pricing policies 


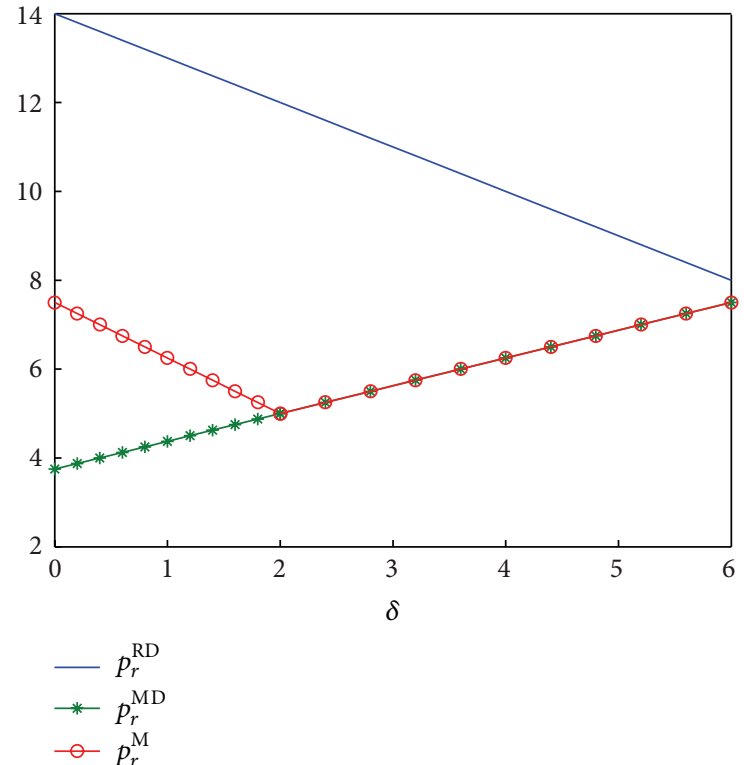

FIGURE 11: Dominant retailer's prices in different channels when $\beta=$ 0.8 .

after they open their Internet stores and discuss the impacts of the dominant retailer's bargaining power and consumers' disutility of purchasing a product from Internet store on the manufacturer and dominant retailer's pricing strategies. Finally, we conduct numerical examples to illustrate the theoretical results.

We obtain some new results differing from those in the literature. We find that the optimal choices for the manufacturer and dominant retailer to open an Internet store are largely determined by their respective setup costs, which are closely related to the dominant retailer's bargaining power and consumers' disutility of buying from Internet store. It is worth mentioning that multichannel retailing for the dominant retailer is not necessarily the best strategy. In other words, if the dominant retailer opens an Internet store, the marketing plan for him to attract more consumers by charging a lower price is impossible to achieve, and he can induce the manufacturer to open an Internet store to compete with him. Only when the setup cost for the dominant retailer to open an Internet store is sufficiently low, then he is profitable.

What is more, we also find that the manufacturer's optimal price at her Internet store is not always being lower than the dominant retailer's. For example, if the consumers' disutility of buying from Internet store is sufficiently high, the manufacturer must provide strong price incentives for consumers to purchase the product from the Internet store.

Although this research provides new insights for the manufacturer and dominant retailer to open an Internet store and set prices in a supply chain, there are several directions that could be extended. First, this study assumed that all information is known to the manufacturer and dominant retailer in our model. However, information could be asymmetric in the supply chain since both players have private information about their own internal variable costs, for example, the setup cost of opening an Internet store, customers' purchase patterns, and search costs. Therefore, we can explore the competitive equilibrium under asymmetric information settings. Second, we assume that consumers' disutility of buy from Internet store is independent of the unit transportation cost, which can be relaxed in the future research. Third, trade credit is widely used in practice and has important impact on supply chain management [3941]. In recent years, trade credit has become one of the major transactions between suppliers and retailers in a value chain. For example, Wal-Mart, Carrefour, and GOME (a large Chinese home appliance chain retailer) even delayed payments to their suppliers for as long as one year [42]. Hence, it is worthy to understand how the trade credit affects supply channel configuration together with pricing strategies in the E-commerce market. A final issue worthy of investigation is how different types of customers affect the manufacturer and dominant retailer's channel selection strategies. We leave these questions for future research.

\section{Appendices}

\section{A. Equilibrium Outcome of the Four Channel Structures}

Proof of Lemma 6. (1) In the T-channel, both the manufacturer and dominant retailer do not open their Internet stores. There is only the dominant retailer's physical store in the market. So the dominant retailer acts as a monopolist and optimally charges a price $V-t$ such that the market is just covered. For the manufacturer, given that the dominant retailer's optimal retail price, the optimal wholesale price is $w^{\mathrm{T}}=(1-\beta)(V-t)$. Since the manufacturer produces the product at a constant unit (marginal) cost which is normalized to zero, and the market is just covered, that is, the size of the market is one, the profit for the manufacturer is $\prod_{m}^{\mathrm{T}}=(1-\beta)(V-t)$. Accordingly, the profit for the dominant retailer is $\prod_{r}^{\mathrm{T}}=\beta(V-t)$.

(2) In RD-channel, only the dominant retailer opens an Internet store (RIS). If a consumer locates at a distance from physical store (PS), he will get a net utility of by purchasing the product from PS, and a net utility of by purchasing the product from RIS. To ensure the full market coverage, the dominant retailer charges the monopoly price $V-\delta$ across his two stores and sells the product to all consumers. For the manufacturer, given the dominant retailer's optimal retail price, the optimal wholesale price is $w^{\mathrm{RD}}=(1-\beta)(V-\delta)$. Since the manufacturer produces the product at a constant unit (marginal) cost which is normalized to zero and $t$ the size of the market is one, the profits for the manufacturer and dominant retailer are $\prod_{m}^{\mathrm{RD}}=(1-\beta)(V-\delta)$ and $\prod_{r}^{\mathrm{RD}}=$ $\beta(V-\delta)$, respectively.

(3) In MD-channel, the manufacturer opens an Internet store, but dominant retailer does not. So consumers can have convenient access to the product through the dominant retailer's physical store (PS) at price $p_{r}$ or the manufacturer's Internet store (MIS) at price $p_{m}$; their decision about which store to buy revolves around the comparison of their net 
utility derived from PS $U_{\mathrm{PS}}=V-p_{r}-t x$ and $U_{\mathrm{MIS}}=V-p_{m}-\delta$ by buying the product from MIS. Therefore, the marginal consumers are located at $x=\left(p_{m}-p_{r}+\delta\right) / t$. So the profit functions for the manufacturer and dominant retailer can be written as

$$
\begin{aligned}
& \prod_{m}=w\left[\frac{\left(p_{m}-p_{r}+\delta\right)}{t}\right]+p_{m}\left[\frac{\left(p_{r}-p_{m}+t-\delta\right)}{t}\right]-F_{m} \\
& \prod_{r}=\left(p_{r}-w\right)\left[\frac{\left(p_{m}-p_{r}+\delta\right)}{t}\right] .
\end{aligned}
$$

Under the assumption proposed in Section 3, the dominant retailer is the price leader and the manufacturer is the follower. As before, the game is solved backwards. In this market, we firstly need to calculate the manufacturer's optimal price given any dominant retailer's price.

The manufacturer's reaction function can be derived from the first-order condition:

$$
\begin{gathered}
\frac{\partial \prod_{m}}{\partial p_{m}}=\frac{\left[(2-\beta) p_{r}-2 p_{m}+t-\delta\right]}{t}=0, \\
\text { that is } p_{m}=\frac{\left[(2-\beta) p_{r}+t-\delta\right]}{2} .
\end{gathered}
$$

Substituting (A.3) into (A.2), we get

$$
\prod_{r}=\frac{\left[\beta p_{r}\left(t+\delta-\beta p_{r}\right)\right]}{2 t} .
$$

Taking the first-order derivative of (A.4) with respect to $p_{r}$ and letting the derivative be zero, we have

$$
p_{r}^{\mathrm{MD}}=\frac{(t+\delta)}{2 \beta}
$$

Given the wholesale price bargaining process, we can obtain the manufacturer's optimal wholesale price $w^{\mathrm{MD}}=$ $(1-\beta)(t+\delta) / 2 \beta$ and substituting (A.5) into (A.3), we get the manufacturer's optimal retail price:

$$
p_{m}^{\mathrm{MD}}=\frac{(2+\beta) t+(2-3 \beta) \delta}{4 \beta} .
$$

Substituting (A.5) and (A.6) into (A.1) and (A.2), we can obtain the equilibrium profits for the manufacturers and dominant retailer, respectively:

$$
\begin{aligned}
& \prod_{m}^{\mathrm{MD}}=\frac{(t+\delta)}{2 \beta}+\frac{\left[(t-\delta)^{2}-12 t \delta\right]}{16 t}-F_{m} \\
& \prod_{r}^{\mathrm{MD}}=\frac{(t+\delta)^{2}}{8 t} .
\end{aligned}
$$

Proof of Lemma 7. In the M-channel, both the manufacturer and dominant retailer simultaneously open their own Internet stores; then customers are able to purchase a product either from the dominant retailer's physical store (PS) or from the alternative Internet stores (MIS/RIS). They can get a net utility of $U_{\mathrm{PS}}=V-p_{r}-t x$ by buying the product from PS and a net utility of $U_{\text {MIS }}=V-p_{m}-\delta$ by buying the product from MIS and a net utility of $U_{\mathrm{RIS}}=V-p_{r}-\delta$ by buying the product from RIS.

According to the basic model, we know that the dominant retailer first makes pricing decision as the price leader, and the manufacturer is the follower. If the dominant retailer charges a price higher than the manufacturer's price $\left(p_{r}>p_{m}\right)$, then no consumer will buy the product from his Internet store. Under this condition, the dominant retailer makes no sale in his Internet store and makes a profit of $-F_{r}$. Therefore, the demand functions for the manufacturer's Internet store and dominant retailer's physical store are given, respectively, as follows:

$$
\begin{aligned}
D_{\mathrm{MIS}} & =\frac{\left(p_{r}-p_{m}+t-\delta\right)}{t}, \\
D_{\mathrm{PS}} & =\frac{\left(p_{m}-p_{r}+\delta\right)}{t} .
\end{aligned}
$$

Hence, the manufacturer's profit function can be written as

$$
\prod_{m}=\frac{\left[w\left(p_{m}-p_{r}+\delta\right)+p_{m}\left(p_{r}-p_{m}+t-\delta\right)\right]}{t}-F_{m}
$$

From the first-order condition, we have

$$
p_{m}=\frac{\left[(2-\beta) p_{r}+t-\delta\right]}{2} .
$$

Given the condition of $p_{r}>p_{m}$, this implies that $p_{r}>(t-$ $\delta) / \beta$. However, when $p_{r} \leq(t-\delta) / \beta$ and $p_{r}>p_{m}$, we always have $\partial \prod_{m}^{\mathrm{M}} / \partial p_{m}=\left[(2-\beta) p_{r}-2 p_{m}+t-\delta\right] / t>0$.

Therefore, the manufacturer optimally sets its price at $p_{m}=p_{r}$, and her optimal pricing schedule is as follows:

$$
p_{m}= \begin{cases}p_{r}, & p_{r} \leq \frac{t-\delta}{\alpha} \\ \frac{(2-\beta) p_{r}+t-\delta}{2}, & p_{r}>\frac{t-\delta}{\alpha} .\end{cases}
$$

Given the manufacturer's pricing schedule, the dominant retailer's profit is given as follows:

$$
\prod_{r}= \begin{cases}\left(p_{r}-w\right) \frac{\delta}{t}-F_{r}, & p_{r} \leq \frac{t-\delta}{\beta} \\ \left(p_{r}-w\right) \frac{t+\delta-\beta p_{r}}{2 t}-F_{r}, & p_{r}>\frac{t-\delta}{\beta} .\end{cases}
$$

Under the condition of $p_{r}>(t-\delta) / \beta$, the dominant retailer's profit is

$$
\prod_{r}=\frac{\left[\beta p_{r}\left(t+\delta-\beta p_{r}\right)\right]}{2 t}-F_{r}
$$

Taking the first-order derivative of (A.14) with respect to $p_{r}$, and letting the derivative be zero, we have $p_{r}^{\mathrm{M}}=(t+\delta) / 2 \beta$. 
Submitting it into (A.11), we get the manufacturer's optimal price in her Internet store $p_{m}^{\mathrm{M}}=[(2+\beta) t+(2-3 \beta) \delta] / 4 \beta$. Hence, the manufacturer and dominant retailer's optimal profits are $\prod_{m}^{\mathrm{M}}=(t+\delta) / 2 \beta+\left[(t-\delta)^{2}-12 t \delta\right] / 16 t-F_{m}$ and $\prod_{r}^{\mathrm{M}}=(t+\delta)^{2} / 8 t-F_{r}$, respectively.

According to the previous assumption $p_{r}>(t-\delta) / \beta$, which implies that $(t+\delta) / 2 \beta>(t-\delta) / \beta, \delta$ must satisfy $\delta>$ $t / 3$. However, when $\delta<t / 3$, we always have

$$
\left.\frac{\partial \prod_{r}}{\partial p_{r}}\right|_{[(t-\delta) / \beta](-)}>0,\left.\quad \frac{\partial \prod_{r}}{\partial p_{r}}\right|_{[(t-\delta) / \beta](+)}<0 .
$$

So the dominant retailer's optimal retail price in the $\mathrm{M}$ channel is $p_{r}^{\mathrm{M}}=(t-\delta) / \beta$. Therefore, the manufacturer and dominant retailer's optimal profits are $\prod_{m}^{\mathrm{M}}=(t-\delta) / \beta-[(t-$ $\delta) \delta] / t-F_{m}$ and $\prod_{r}^{\mathrm{M}}=[(t-\delta) \delta] / t-F_{r}$, respectively.

\section{B. Strategic Conditions for Opening an Internet Store}

Proofs of Proposition 8 and Corollary 9. From Lemma 6, we analyse the equilibrium profits for the dominant retailer between the T-channel and RD-channel and note that only when $F_{r}<\beta(t-\delta)$, then $\prod_{r}^{\mathrm{RD}}>\prod_{r}^{\mathrm{T}}$. This implies that as long as the setup cost of opening an Internet store satisfies $F_{r}<\beta(t-\delta) \triangleq B_{1}$, it is always optimal to open an Internet store for the dominant retailer. In addition, we note that $\partial B_{1} / \partial \delta=-\beta<0$. So the dominant retailer's strategic motive for opening an Internet store would be weakened by increasing consumers' disutility of purchasing a product from Internet store.

Proofs of Proposition 10 and Corollary 11. From Lemma 6, we analyse the equilibrium profits for the manufacturer between the T-channel and MD-channel and note that only when the setup cost of opening an Internet store satisfies $F_{m}<(t+$ $\delta) / 2 \beta+\left[(t-\delta)^{2}-12 t \delta\right] / 16 t-(1-\beta)(V-t) \triangleq B_{2}$, then $\prod_{m}^{\mathrm{MD}}>$ $\prod_{m}^{\mathrm{T}}$. In addition, we note that $\partial B_{2} / \partial \delta=[4 t-\beta(7 t-\delta)] / 8 \beta t$ and find when $0<\beta<4 t /(7 t-\delta)$, then $\partial B_{2} / \partial \delta>0$, and when $4 t /(7 t-\delta)<\beta<1$, then $\partial B_{2} / \partial \delta<0$.

Proofs of Proposition 12 and Corollary 13. From Lemmas 6 and 7 , we analyse the equilibrium profits for the manufacturer and dominant retailer between the T-channel and M-channel; we note that under the condition of $\delta<t / 3$, only when the setup costs of opening an Internet store for the manufacturer and dominant retailer simultaneously satisfy

$$
\begin{aligned}
& F_{m}<\frac{(t-\delta)}{\beta}-\frac{[(t-\delta) \delta]}{t}-(1-\beta)(V-t) \triangleq B_{3}, \\
& F_{r}<\frac{[(t-\delta) \delta]}{t}-\beta(V-t) \triangleq B_{4},
\end{aligned}
$$

then

$$
\prod_{m}^{\mathrm{M}}>\prod_{m}^{\mathrm{T}}, \quad \prod_{r}^{\mathrm{M}}>\prod_{r}^{\mathrm{T}} \text {. }
$$

Similarly, under the condition of $\delta>t / 3$, only when the setup costs of opening an Internet store for the manufacturer and dominant retailer simultaneously satisfy

$$
\begin{aligned}
& F_{m}<\frac{(t+\delta)}{2 \beta}+\frac{\left[(t-\delta)^{2}-12 t \delta\right]}{16 t}-(1-\beta)(V-t) \triangleq B_{5}, \\
& F_{r}<\frac{(t+\delta)^{2}}{8 t}-\beta(V-t) \triangleq B_{6}
\end{aligned}
$$

then

$$
\prod_{m}^{\mathrm{M}}>\prod_{m}^{\mathrm{T}}, \quad \prod_{r}^{\mathrm{M}}>\prod_{r}^{\mathrm{T}} .
$$

In addition, we note that both $\partial B_{3} / \partial \delta=-[t+\beta(t-$ $2 \delta)] / \beta t<0$ and $\partial B_{4} / \partial \delta=(t-2 \delta) / t>0$ are held under the condition of $\delta<t / 3$. Furthermore, under the condition of $\delta>t / 3$, we also find that when $0<\beta<4 t /(7 t-\delta)$, then $\partial B_{5} / \partial \delta>0$, and when $4 t /(7 t-\delta)<\beta<1$, then $\partial B_{5} / \partial \delta<0$; $\partial B_{6} / \partial \delta=2(t+\delta) / 8 t>0$.

Proofs of Proposition 14 and Corollary 15. From Lemmas 6 and 7 , we analyse the manufacturer's equilibrium profits in the $\mathrm{RD}$-channel and $\mathrm{M}$-channel; we note that under the condition of $\delta<t / 3$, only when the setup cost of opening an Internet store for her satisfies $F_{m}<(t-\delta) / \beta-[(t-\delta) \delta] / t-$ $(1-\beta)(V-\delta) \triangleq B_{7}$, then $\prod_{m}^{\mathrm{M}}>\prod_{m}^{\mathrm{RD}}$. In addition, we find $\partial B_{7} / \partial \delta=-\left[\left(1+\beta^{2}\right) t-2 \beta \delta\right] / \beta t<0$.

But under the condition of $\delta>t / 3$, only when the setup cost of opening an Internet store for her satisfies $F_{m}<(t+$ $\delta) / 2 \beta+\left[(t-\delta)^{2}-12 t \delta\right] / 16 t-(1-\beta)(V-\delta) \triangleq B_{8}$, then $\prod_{m}^{\mathrm{M}}>\prod_{m}^{\mathrm{RD}}$. In addition, $\partial B_{8} / \partial \delta=\left[\beta(t+\delta)+4 t\left(1-2 \beta^{2}\right)\right] / 8 \beta t$, we find that when $0<\beta<\left[(t+\delta)+\sqrt{(t+\delta)^{2}+128 t^{2}}\right] / 16 t$, then $\partial B_{8} / \partial \delta>0$, and when $\left[(t+\delta)+\sqrt{(t+\delta)^{2}+128 t^{2}}\right] / 16 t<$ $\beta<1$, then $\partial B_{8} / \partial \delta<0$.

Proofs of Proposition 16. From Lemmas 6 and 7, we analyse the dominant retailer's equilibrium profits in the MD-channel and M-channel and note that when $\delta<t / 3$, then $\prod_{r}^{\mathrm{M}}-$ $\prod_{r}^{\mathrm{MD}}=-(t-3 \delta)^{2} / 8 t-F_{r}<0$, and when $\delta>t / 3$, then $\prod_{r}^{\mathrm{M}}-\prod_{r}^{\mathrm{MD}}=-F_{r}<0$. These imply that when the manufacturer has operated an Internet store, the best choice for dominant retailer is not to open an Internet store.

Proofs of Proposition 17 and Corollary 18. From Lemmas 6 and 7 , we analyse the dominant retailer's equilibrium profits in the MD-channel and M-channel and note that under the condition of $\delta<t / 3$, then $\prod_{m}^{\mathrm{M}}-\prod_{m}^{\mathrm{MD}}=[8 t(t-3 \delta)-\beta[(t+$ $\left.\left.\delta)^{2}-16 \delta^{2}\right] / 8 t\right] / 16 \beta t$. This implies that the manufacturer will open her Internet store when the dominant retailer opens an 
Internet store and the setup costs of opening an Internet store for her satisfies

$$
\begin{aligned}
B_{9} & \triangleq \frac{(t+\delta)}{2 \beta}+\frac{\left[(t-\delta)^{2}-12 t \delta\right]}{16 t} \\
& <F_{m}<\frac{(t-\delta)}{\beta}-\frac{[(t-\delta) \delta]}{t} \triangleq B_{10} .
\end{aligned}
$$

In addition, we find that when $0<\beta<4 t /(7 t-\delta)$, then $\partial B_{9} / \partial \delta>0$ and when $4 t /(7 t-\delta)<\beta<1$, then $\partial B_{9} / \partial \delta<0$ and $\partial B_{10} / \partial \delta=-[t+\beta(t-2 \delta)] / \beta t<0$.

\section{The Manufacturer/Dominant Retailers Pricing Policies}

Proof of Proposition 19. In the MD-channel, we, respectively, differentiate between $p_{m}^{\mathrm{MD}}$ and $p_{r}^{\mathrm{MD}}$ with respect to $\beta$ and find that $\partial p_{m}^{\mathrm{MD}} / \partial \beta=\partial p_{r}^{\mathrm{MD}} / \partial \beta=-(t+\delta) / 2 \beta^{2}<0$. For any given $\beta$, differentiating between $p_{m}^{\mathrm{MD}}$ and $p_{r}^{\mathrm{MD}}$ with respect to $\delta$, we have $\partial p_{r}^{\mathrm{MD}} / \partial \delta=1 / 2 \beta>0$ and $\partial p_{m}^{\mathrm{MD}} / \partial \delta=(2-3 \beta) / 4 \beta$, and if $\beta \in(0,2 / 3)$, then $\partial p_{m}^{\mathrm{MD}} / \partial \delta>0$; if $\beta \in(2 / 3,1)$, then $\partial p_{m}^{\mathrm{MD}} / \partial \delta<0$. In addition, we find that $p_{m}^{\mathrm{MD}}-p_{r}^{\mathrm{MD}}=(t-$ $3 \delta) / 4$; it is obvious that when $\delta<t / 3$, then $p_{m}^{\mathrm{MD}}>p_{r}^{\mathrm{MD}}$; when $\delta=t / 3$, then $p_{m}^{\mathrm{MD}}=p_{r}^{\mathrm{MD}}$, and when $\delta>t / 3$, then $p_{m}^{\mathrm{MD}}<p_{r}^{\mathrm{MD}}$.

Proof of Proposition 20. In the M-channel, we, respectively, differentiate between $p_{m}^{\mathrm{M}}$ and $p_{r}^{\mathrm{M}}$ with respect to $\beta$ and find that when $\delta<t / 3$, then $\partial p_{m}^{\mathrm{M}} / \partial \beta=\partial p_{r}^{\mathrm{M}} / \partial \beta=-(t-\delta) / \beta^{2}<0$ and when $\delta>t / 3$, then $\partial p_{m}^{\mathrm{M}} / \partial \beta=\partial p_{r}^{\mathrm{M}} / \partial \beta=-(t+\delta) / 2 \beta^{2}<$ 0 . For any given $\beta$, we, respectively, differentiate between $p_{m}^{\mathrm{M}}$ and $p_{r}^{\mathrm{M}}$ with respect to $\delta$ and find that when $\delta<t / 3$, then $\partial p_{m}^{\mathrm{M}} / \partial \delta=\partial p_{r}^{\mathrm{M}} / \partial \delta=-1 / \beta<0$; when $\delta>t / 3$, then $\partial p_{m}^{\mathrm{M}} / \partial \delta=(2-3 \beta) / 4 \beta$ and $\partial p_{r}^{\mathrm{M}} / \partial \delta=1 / 2 \beta>0$.

It is easy to note that when $\beta \in(0,2 / 3)$, then $\partial p_{m}^{\mathrm{M}} / \partial \delta>0$, but when $\beta \in(2 / 3,1)$, then $\partial p_{m}^{\mathrm{M}} / \partial \delta<0$.

Proof of Proposition 21. From Lemmas 6 and 7, we note that $\partial w^{\mathrm{RD}} / \partial \delta=-(1-\beta)<0$ and $\partial w^{\mathrm{MD}} / \partial \delta=(1-\beta) / 2 \beta>0$. In addition, if $\delta<t / 3$, then $\partial w^{\mathrm{M}} / \partial \delta=-(1-\beta) / \beta<0$; if $\delta>t / 3$, then $\partial w^{\mathrm{MD}} / \partial \delta=(1-\beta) / 2 \beta>0$.

Proof of Proposition 22. From the proofs of Propositions 19 and 20 , we note that, when $\delta<t / 3$, if $\beta \in(0,2 / 3)$, then $\partial p_{m}^{\mathrm{MD}} / \partial \delta>0, \partial p_{m}^{\mathrm{M}} / \partial \delta<0$, but if $\beta \in(2 / 3,1)$, then $\partial p_{m}^{\mathrm{MD}} / \partial \delta<0, \partial p_{m}^{\mathrm{M}} / \partial \delta<0$; when $\delta>t / 3$, if $\beta \in(0,2 / 3)$, then $\partial p_{m}^{\mathrm{MD}} / \partial \delta=\partial p_{m}^{\mathrm{M}} / \partial \delta>0$, but if $\beta \in(2 / 3,1)$, then $\partial p_{m}^{\mathrm{MD}} / \partial \delta=\partial p_{m}^{\mathrm{M}} / \partial \delta<0$.

Proof of Proposition 23. From Lemmas 6 and 7, we note that $\partial p_{r}^{\mathrm{RD}} / \partial \delta=-1<0$ and $\partial p_{r}^{\mathrm{MD}} / \partial \delta=1 / 2 \alpha>0$. In addition, if $\delta<t / 3$, then $\partial p_{r}^{\mathrm{M}} / \partial \delta=-1 / \alpha<0$; if $\delta>t / 3$, then $\partial p_{r}^{\mathrm{M}} / \partial \delta=$ $1 / 2 \alpha>0$.

\section{Abbreviations}

$\mathrm{U}_{\mathrm{K}}$ : The consumer's utility of purchasing the product from $\mathrm{K}$ store,

$\mathrm{K} \in\{\mathrm{PS}, \mathrm{RIS}, \mathrm{MIS}\}$

$V: \quad$ The value of consumers willing to pay for the product

$\delta$ : The consumers' disutility of purchasing the product from Internet store (MIS/RIS)

$t$ : The per unit transportation cost of purchasing the product from physical store (PS)

$\beta$ : $\quad$ The dominant retailer's bargaining power in the distribution channel

$w^{\mathrm{j}}$ : The manufacturer's wholesale price in the $\mathrm{j}$-channel, $\mathrm{j} \in\{\mathrm{T}, \mathrm{RD}, \mathrm{MD}, \mathrm{M}\}$

$p_{r}^{\mathrm{j}}$ : The dominant retailer's price in the

j-channel, $\mathrm{j} \in\{\mathrm{T}, \mathrm{RD}, \mathrm{MD}, \mathrm{M}\}$

$p_{m}^{\mathrm{j}}: \quad$ The manufacturer's price in the $\mathrm{j}$-channel, $\mathrm{j} \in\{\mathrm{MD}, \mathrm{M}\}$

$F_{m} / F_{r}$ : The setup cost of opening an Internet store by the manufacturer/dominant retailer

$\Pi_{m}^{\mathrm{j}} / \Pi_{r}^{\mathrm{j}}$ : The manufacturer/dominant retailer's profit in the $\mathrm{j}$-channel, $\mathrm{j} \in\{\mathrm{T}, \mathrm{RD}, \mathrm{MD}, \mathrm{M}\}$.

\section{Conflict of Interests}

The authors declare that there is no conflict of interests regarding the publication of this paper.

\section{Acknowledgments}

This research has been supported by the National Natural Science Foundation of China (71271225), Chongqing's Natural Science Foundation (cstc2012jjA1404), and the Open Fund of Chongqing Key Laboratory of Logistics (CQKLL12001).

\section{References}

[1] L. Hsiao and Y.-J. Chen, "Strategic motive for introducing internet channels in a supply chain," Production and Operations Management, vol. 23, no. 1, pp. 36-47, 2014.

[2] I. Geyskens, K. Gielens, and M. G. Dekimpe, "The market valuation of Internet channel additions," Journal of Marketing, vol. 66, no. 2, pp. 102-119, 2002.

[3] W.-Y. K. Chiang, D. Chhajed, and J. D. Hess, "Direct marketing, indirect profits: a strategic analysis of dual-channel supplychain design," Management Science, vol. 49, no. 1, pp. 1-20, 2003.

[4] S.-H. Chun and J.-C. Kim, "Pricing strategies in B2C electronic commerce: analytical and empirical approaches," Decision Support Systems, vol. 40, no. 2, pp. 375-388, 2005.

[5] S. K. Mukhopadhyay, X. Zhu, and X. Yue, "Optimal contract design for mixed channels under information asymmetry," Production and Operations Management, vol. 17, no. 6, pp. 641650, 2008. 
[6] G. S. Cai, "Channel selection and coordination in dual-channel supply chains," Journal of Retailing, vol. 86, no. 1, pp. 22-36, 2010.

[7] K. Takahashi, T. Aoi, D. Hirotani, and K. Morikawa, "Inventory control in a two-echelon dual-channel supply chain with setup of production and delivery," International Journal of Production Economics, vol. 133, no. 1, pp. 403-415, 2011.

[8] D. W. Carlton and J. A. Chevalier, "Free riding and sales strategies for the Internet," Journal of Industrial Economics, vol. 49, no. 4, pp. 441-461, 2001.

[9] K. D. Antia, M. Bergen, and S. Dutta, "Competing with gray markets," MIT Sloan Management Review, vol. 46, no. 1, pp. 6369, 2004.

[10] J. Shin, "How does free riding on customer service affect competition?" Marketing Science, vol. 26, no. 4, pp. 488-503, 2007.

[11] G. Iyer and J. M. Villas-Boas, "A bargaining theory of distribution channels," Journal of Marketing Research, vol. 40, no. 1, pp. 80-100, 2003.

[12] A. Dukes and Y. Liu, "In-store media and distribution channel coordination," Marketing Science, vol. 29, no. 1, pp. 94-107, 2010.

[13] H. Ahn, I. Duenyas, and R. Zhang, "Price competition between retailers and manufacturer-owned stores," Working Paper, University of California at Berkeley, 2002.

[14] K. Cattani, W. Gilland, H. S. Heese, and J. Swaminathan, "Boiling frogs: pricing strategies for a manufacturer adding a direct channel that competes with the traditional channel," Production and Operations Management, vol. 15, no. 1, pp. 4056, 2006.

[15] K.-Y. Chen, M. Kaya, and Ö. Özer, "Dual sales channel management with service competition," Manufacturing and Service Operations Management, vol. 10, no. 4, pp. 654-675, 2008.

[16] G. Hua, S. Wang, and T. C. E. Cheng, "Price and lead time decisions in dual-channel supply chains," European Journal of Operational Research, vol. 205, no. 1, pp. 113-126, 2010.

[17] W. S. Yoo and E. Lee, "Internet channel entry: a strategic analysis of mixed channel structures," Marketing Science, vol. 30, no. 1, pp. 29-41, 2011.

[18] Y. Xiong, W. Yan, K. Fernandes, Z.-K. Xiong, and N. Guo, "“Bricks vs. clicks": the impact of manufacturer encroachment with a dealer leasing and selling of durable goods," European Journal of Operational Research, vol. 217, no. 1, pp. 75-83, 2012.

[19] Q. Lu and N. Liu, "Pricing games of mixed conventional and e-commerce distribution channels," Computers and Industrial Engineering, vol. 64, no. 1, pp. 122-132, 2013.

[20] Q. Xu, Z. Liu, and B. Shen, "The impact of price comparison service on pricing strategy in a dual-channel supply chain," Mathematical Problems in Engineering, vol. 2013, Article ID 613528, 13 pages, 2013.

[21] C. A. Ingene and M. E. Parry, "Channel coordination when retailers compete," Marketing Science, vol. 14, no. 4, pp. 360-377, 1995.

[22] A. A. Tsay and N. Agrawal, "Channel conflict and coordination in the E-commerce age," Production and Operations Management, vol. 13, no. 1, pp. 93-110, 2004.

[23] J. Raju and Z. J. Zhang, "Channel coordination in the presence of a dominant retailer," Marketing Science, vol. 24, no. 2, pp. 254262, 2005.

[24] K. L. Webb and C. J. Lambe, "Internal multi-channel conflict: an exploratory investigation and conceptual framework," Industrial Marketing Management, vol. 36, no. 1, pp. 29-43, 2007.
[25] S. K. Mukhopadhyay, D.-Q. Yao, and X. Yue, "Information sharing of value-adding retailer in a mixed channel hi-tech supply chain," Journal of Business Research, vol. 61, no. 9, pp. 950-958, 2008.

[26] R. Yan, "Managing channel coordination in a multi-channel manufacturer-retailer supply chain," Industrial Marketing Management, vol. 40, no. 4, pp. 636-642, 2011.

[27] E. Cao, Y. Ma, C. Wan, and M. Lai, "Contracting with asymmetric cost information in a dual-channel supply chain," Operations Research Letters, vol. 41, no. 4, pp. 410-414, 2013.

[28] D. Q. Yao and J. J. Liu, "Competitive pricing of mixed retail and e-tail distribution channels," Omega, vol. 33, no. 3, pp. 235-247, 2005.

[29] Y. Liu, S. Gupta, and Z. J. Zhang, "Note on self-restraint as an online entry-deterrence strategy," Management Science, vol. 52, no. 11, pp. 1799-1809, 2006.

[30] Z. Cheng and B. R. Nault, "Internet channel entry: retail coverage and entry cost advantage," Information Technology and Management, vol. 8, no. 2, pp. 111-132, 2007.

[31] X. Zhang, "Retailers' multichannel and price advertising strategies," Marketing Science, vol. 28, no. 6, pp. 1080-1094, 2009.

[32] W. Huang and J. M. Swaminathan, "Introduction of a second channel: implications for pricing and profits," European Journal of Operational Research, vol. 194, no. 1, pp. 258-279, 2009.

[33] H. Hotelling, "Stability in competition," The Economic Journal, vol. 39, no. 153, pp. 41-57, 1929.

[34] J. Zhang, "The perils of behavior-based personalization," Marketing Science, vol. 30, no. 1, pp. 170-186, 2011.

[35] T. Kabiraj and C. Lee, "Licensing contracts in hotelling structure," Theoretical Economics Letters, vol. 1, no. 3, pp. 57-62, 2011.

[36] H. Wang and T. Nariu, "Distribution channel management in an internet age: equilibrium and social welfare," Journal of Industry, Competition and Trade, vol. 12, no. 3, pp. 285-298, 2012.

[37] M. Lijesen, "Hotelling's webshop," Journal of Economics, vol. 109, no. 2, pp. 193-200, 2013.

[38] R. Gulati and J. Garino, "Get the right mix of bricks \& clicks," Harvard Business Review, vol. 78, no. 3, pp. 107-214, 2000.

[39] K.-J. Chung, S.-D. Lin, and H. M. Srivastava, "The complete solution procedures for the mathematical analysis of some families of optimal inventory models with order-size dependent trade credit and deterministic and constant demand," Applied Mathematics and Computation, vol. 219, no. 1, pp. 142-157, 2012.

[40] K.-J. Chung, S.-D. Lin, and H. M. Srivastava, "The inventory models under conditional trade credit in a supply chain system," Applied Mathematical Modelling. Simulation and Computation for Engineering and Environmental Systems, vol. 37, no. 24, pp. 10036-10052, 2013.

[41] K.-J. Chung, S.-D. Lin, and H. M. Srivastava, “The inventory models for deteriorating items in the discounted cash-flows approach under conditional trade credit and cash discount in a supply chain system," Applied Mathematics and Information Sciences, vol. 8, no. 5, pp. 2103-2111, 2014.

[42] J. Luo and Q. Zhang, "Trade credit: a new mechanism to coordinate supply chain," Operations Research Letters, vol. 40, no. 5, pp. 378-384, 2012. 


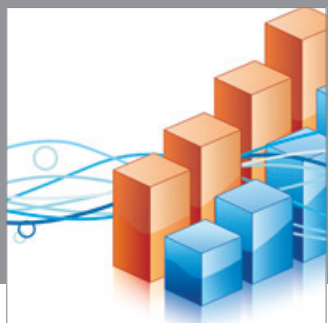

Advances in

Operations Research

mansans

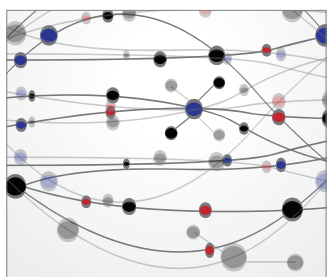

The Scientific World Journal
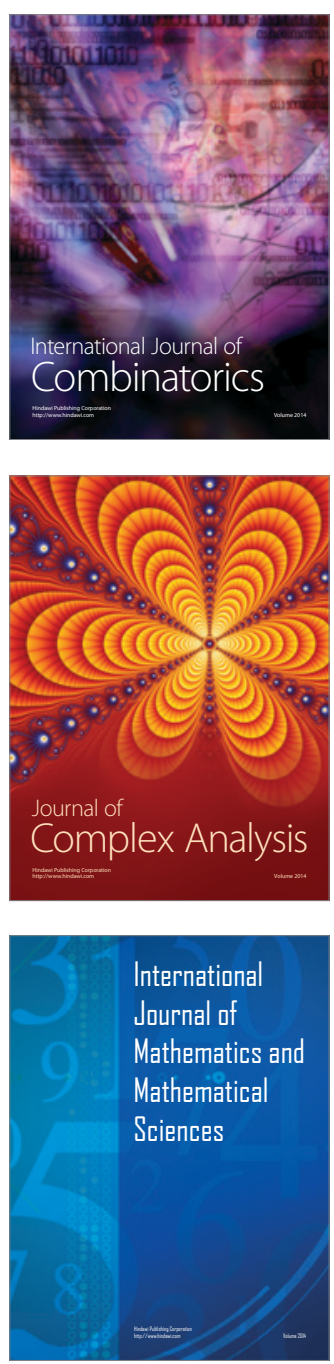
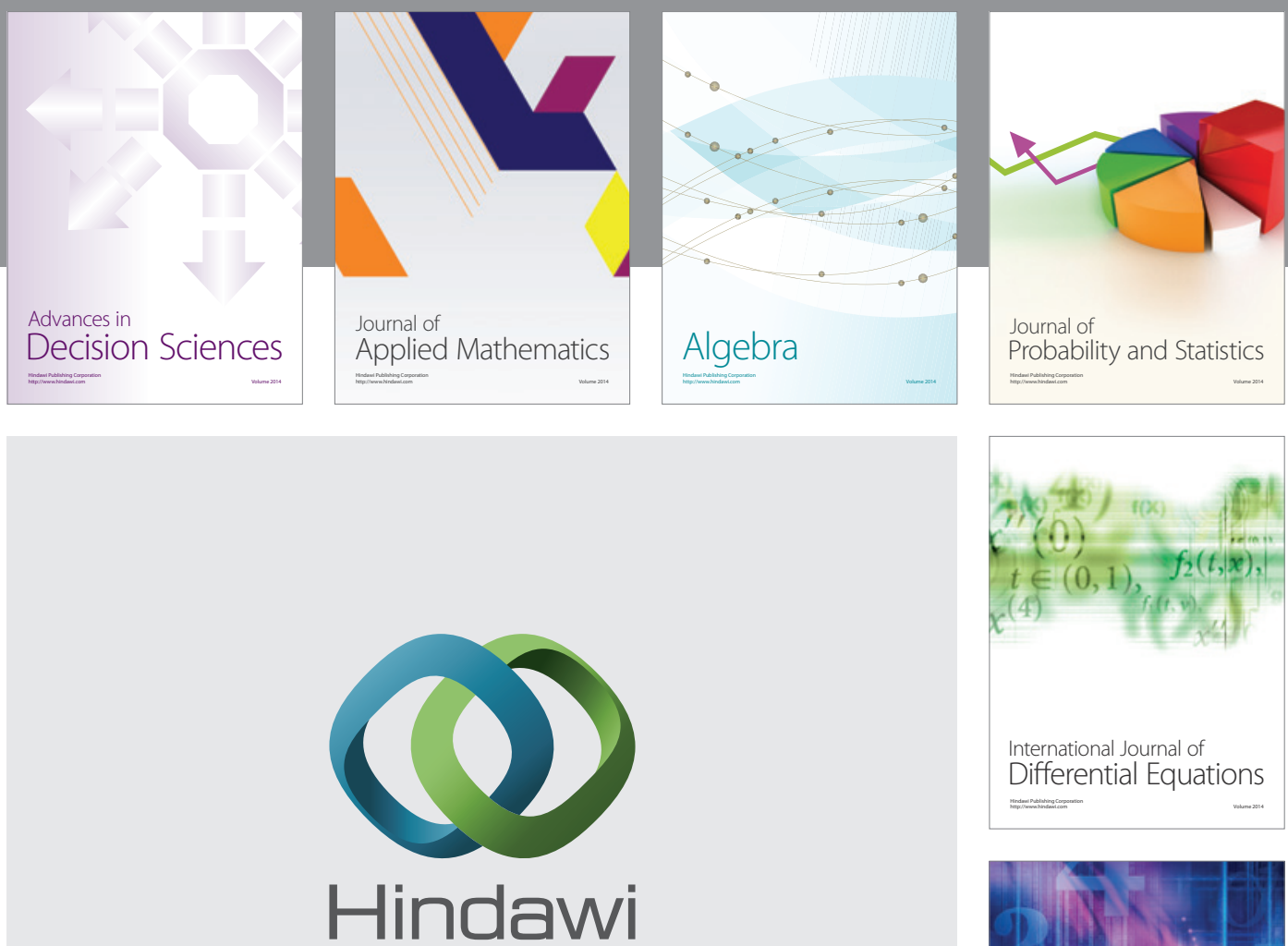

Submit your manuscripts at http://www.hindawi.com
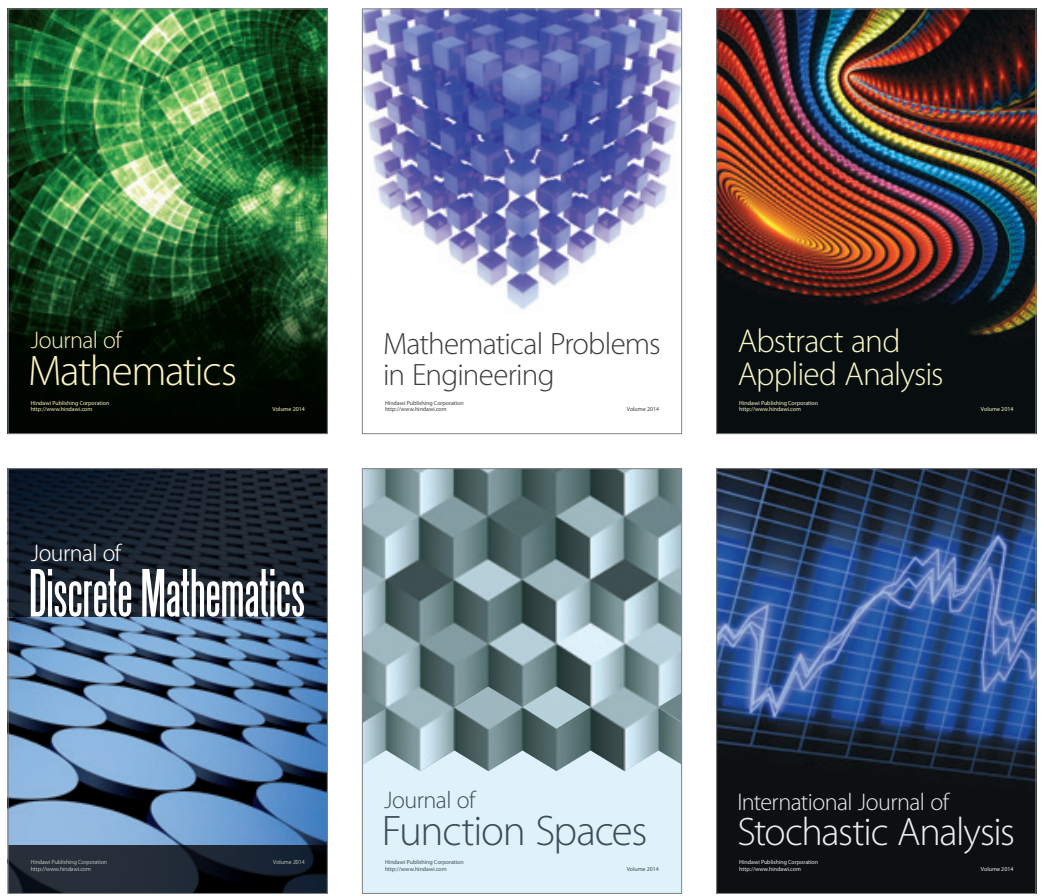

Journal of

Function Spaces

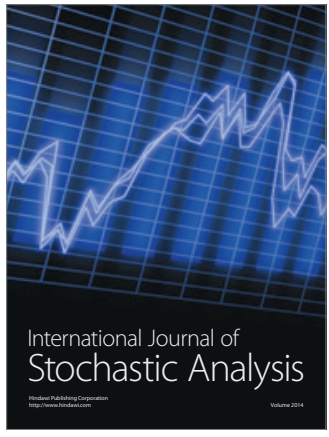

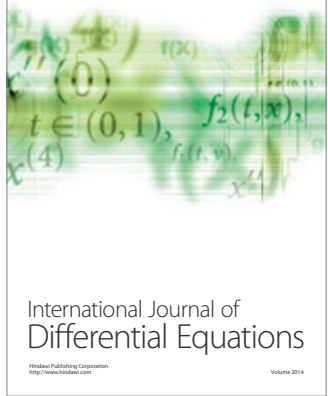
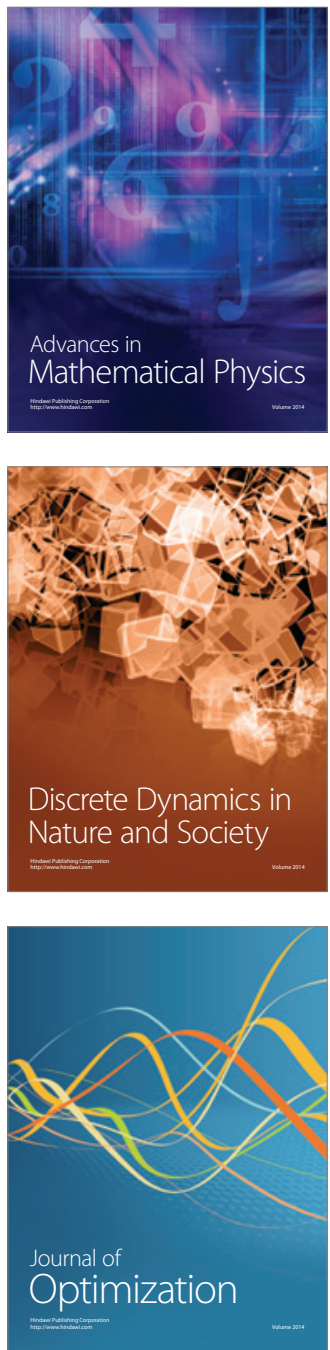